Universidad de Lima

Facultad de Comunicación

Carrera de Comunicación

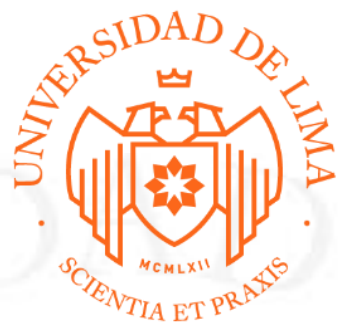

\title{
¿LOS ETIQUETADOS NUTRICIONALES AYUDAN A MEJORAR LOS HÁBITOS ALIMENTICIOS DE LOS CONSUMIDORES?
}

Tesis para optar el título profesional de Licenciado en Comunicación

\author{
Paloma Andrea Ortiz Martínez
}

Código 20130933

\section{Asesor}

Peter Busse

Lima - Perú

Junio del 2019 
¿LOS ETIQUETADOS NUTRICIONALES AYUDAN A MEJORAR LOS HÁBITOS ALIMENTICIOS DE LOS CONSUMIDORES? 


\section{TABLA DE CONTENIDO}

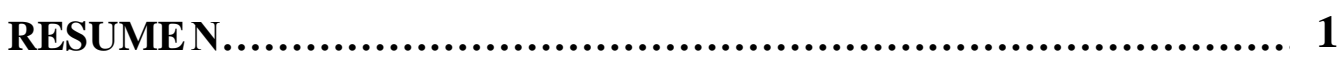

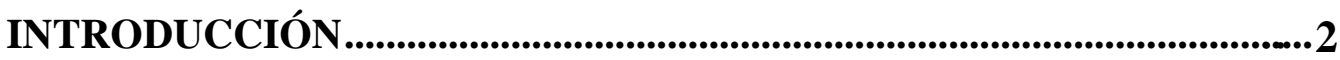

CAPÍTULO I: ESTADO DEL ARTE .................................... 3

1.1. Rol de los etiquetados en el consumo de alimentos .................................. 3

1.1.1. Tendencias de alimentación................................ 3

1.1.2. Etiquetado de alimentos... ...........................................................4

1.1.3. Educación sobre los etiquetados y la obesidad infantil ........................... 5

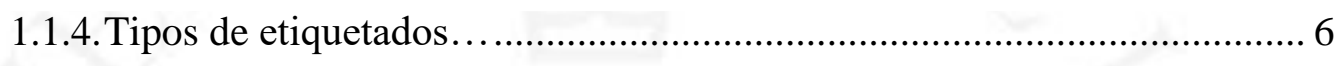

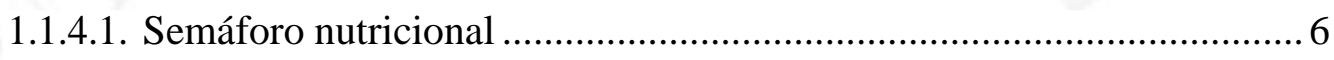

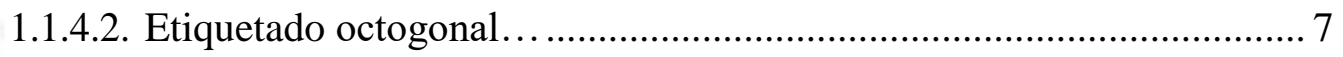

1.1.4.3. Propuesta de etiquetado canadiense ................................................ 8

1.1.4.4. Etiquetado de estrellas (Australia y Nueva Zelanda).......................... 9

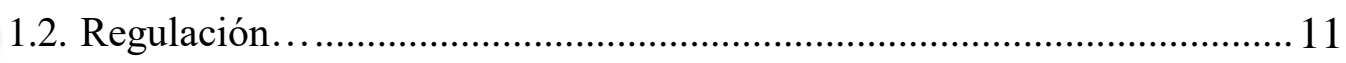

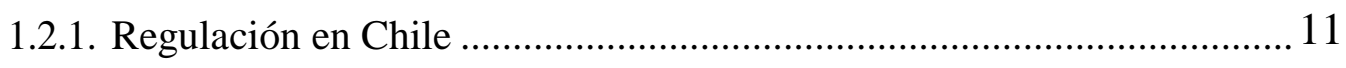

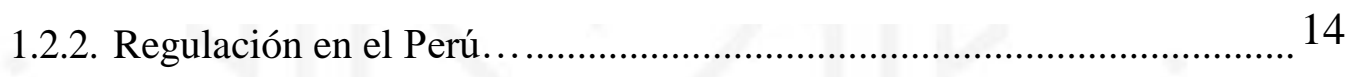

1.3. ¿Qué dicen los estudios recientes sobre el uso de etiquetados? (2013 2018)............................................................... 19

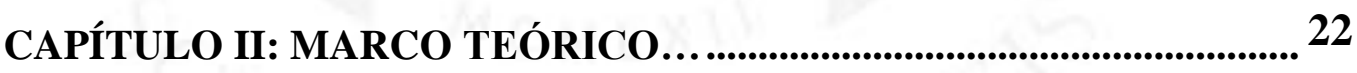

2.1. Modelo económico racional ..................................................................... 22

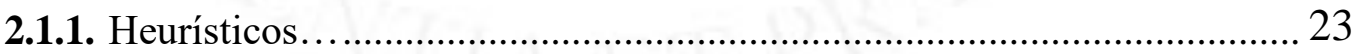

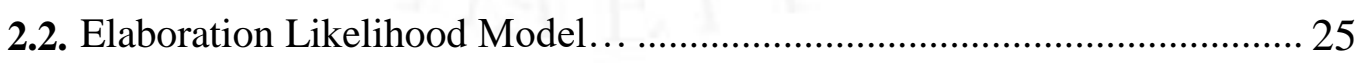

CAPÍTULO III: OBJETIVOS Y JUSTIFICACIÓN.......................................29

CAPÍTULO IV: METODOLOGÍA..............................................................32

CAPÍTULO V: RESULTADOS .........................................................................37

CAPÍTULO VI: DISCUSIÓN......................................................................4 47

CONCLUSIÓN................................................................................................. 54

REFERENCIAS.......................................................................................... 55

ANEXOS ........................................................................................................................ 64 


\section{ÍNDICE DE FIGURAS}

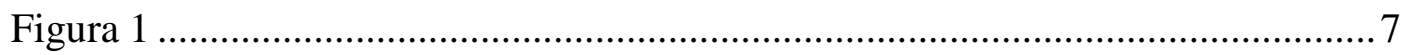

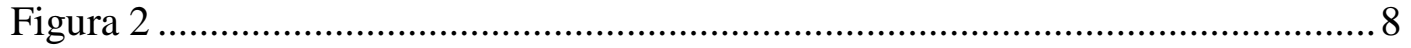

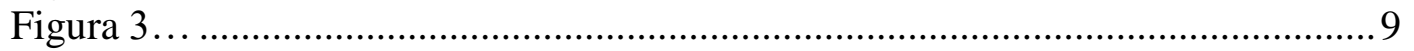

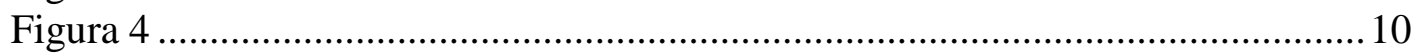

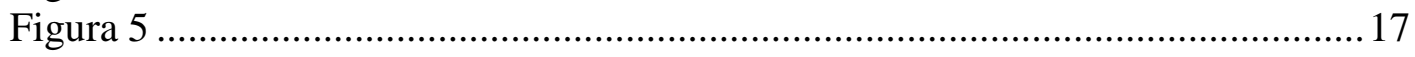

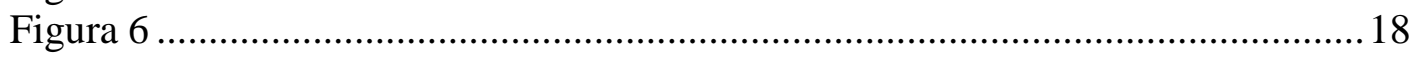

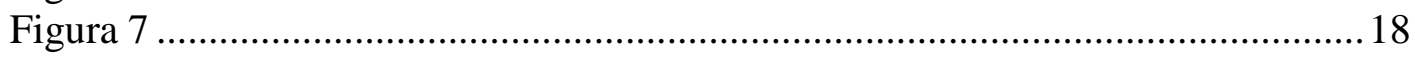

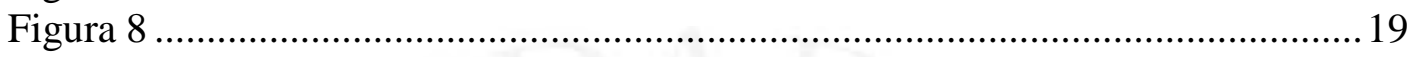

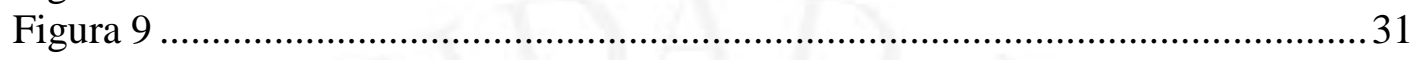

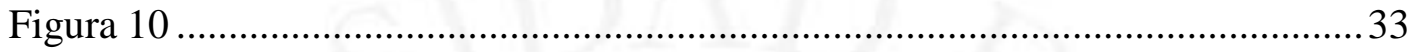

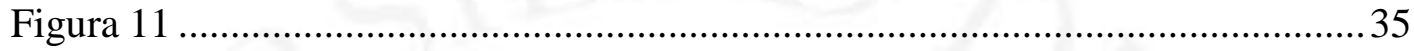

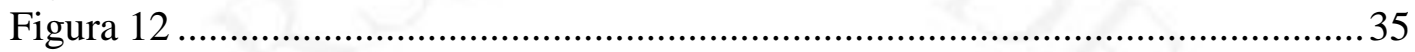

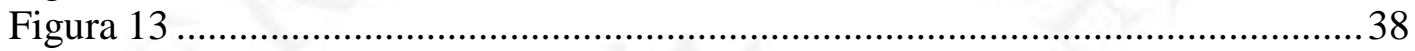

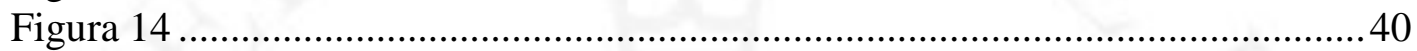

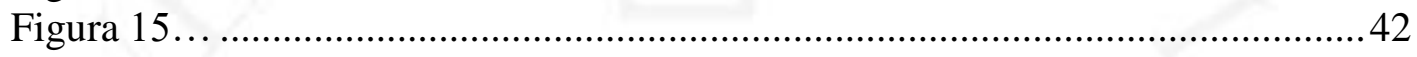

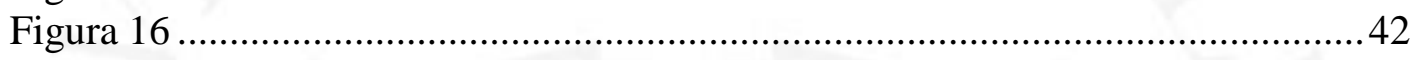

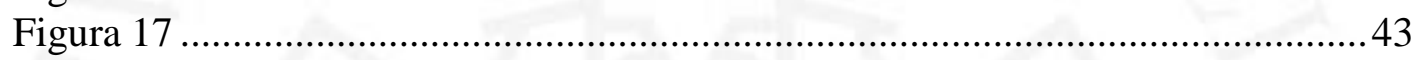

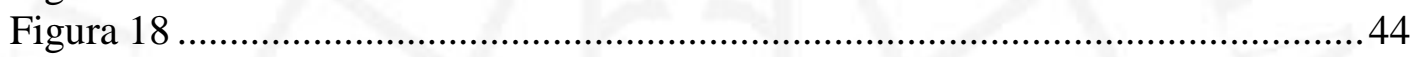

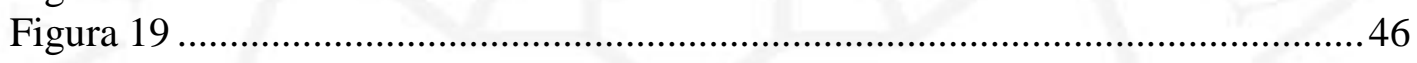

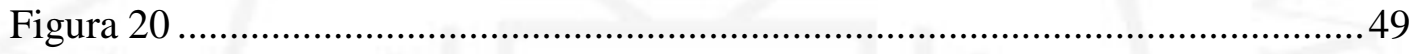




\section{ÍNDICE DE ANEXOS}

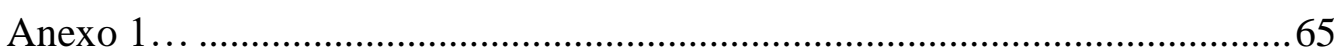

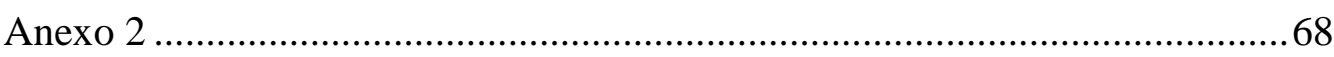

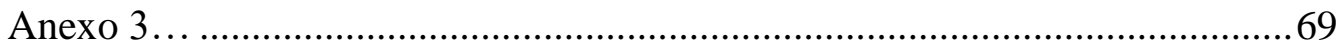




\section{RESUMEN}

Según el informe del INEI (2018), el 37,3\% de las personas de 15 y más años de edad tienen sobrepeso y el 22,7\% tiene obesidad en el Perú, esto refleja graves problemas en su salud. Es por ello que el Gobierno Peruano, desde el año 2013 ha procurado implementar medidas regulatorias para el uso de etiquetados nutricionales. Se busca con la incorporación de estos etiquetados que los consumidores responsables de su salud obtengan información veraz de los nutrientes de los productos a adquirir. En el proceso de implementación de los etiquetados, el debate se centró en la incorporación de dos etiquetados diferentes: octogonal y semáforo. Hacemos notar que, en nuestro país, únicamente se han realizado estudios en base a las dos proposiciones mencionadas anteriormente. Es por ello que en este estudio se investigó y analizó dos propuestas alternativas de rotulados en los consumidores peruanos: el etiquetado canadiense y el etiquetado australiano. Se quiso conocer el nivel de comprensión y la posible influencia que tienen estas dos alternativas en la población. Se pudo concluir que las personas tienen interés respecto a la información nutricional y que los etiquetados nutricionales logran causar cierto impacto en las personas, sobre todo el canadiense, sin embargo, un grave problema es la desinformación sobre el tema. 


\section{INTRODUCCIÓN}

La Ley de Alimentación Saludable fue aprobada en el año 2013, pero permaneció sin Reglamento hasta junio del 2017. Por muchos meses hubo un debate sobre qué etiquetado sería mejor utilizar: el octogonal o el semáforo nutricional. De esta manera se logró que el tema solo entrara en discusión y fuera archivado, para luego volver a ser abierto en el Congreso del Perú. Logrando ralentizar el hallazgo de una solución clara, debido a todos los detractores que existían detrás de ambas propuestas (RPP, 2018).

En diciembre del 2016, el congresista fujimorista Daniel Salaverry presentó el Decreto Legislativo 1304, que norma el etiquetado de los productos industriales (Congreso de la República del Perú, 2016), con contenidos altos en “azúcar”, "grasas saturadas" y "sal". Debido a que se descubrió que uno de cada 4 menores de edad posee una acumulación alarmante de grasa en su cuerpo (Observatorio de Nutrición y Estudio del Sobrepeso y Obesidad, 2016). Finalmente, el 16 de junio del 2018 se llegó a una decisión y se optó por elegir al etiquetado octogonal (RPP, 2018). Sin embargo, dentro de toda esta discusión se recalcó un problema bastante serio, y es que las opciones de etiquetado (octógonos y semáforo) que se proponían eran muy complicadas de entender (RPP, 2018).

En el Perú la mayoría de investigaciones se han enfocado en estudiar las dos proposiciones mencionadas anteriormente: etiquetado semáforo y el octogonal, ya que estas son las más conocidas y usadas internacionalmente; sin embargo, existen otros tipos de etiquetados que favorecen la comprensión del usuario. Estos se usan en otros países y no han sido analizados ni probados en el Perú. Es por ello, que este estudio investigará y analizará dos propuestas alternativas de rotulados en los consumidores peruanos: el etiquetado canadiense, usado en Canadá, y el etiquetado de estrellas, que se usa en países como Australia y Nueva Zelanda. 


\section{CAPÍTULO 1: ESTADO DEL ARTE}

En este capítulo se presentan los distintos tipos de etiquetados y los principales conceptos que serán utilizados para el presente estudio. Adicionalmente, se muestran los diversos estudios que se han hecho en distintos países respecto al etiquetado nutricional, y cómo éste ha ido influenciando en las personas.

\subsection{Rol de los etiquetados en el consumo de alimentos}

\subsubsection{Tendencias de alimentación}

Con el pasar de estos últimos años el consumidor ha empezado a demandar a las industrias de alimentos productos más sanos, sostenibles, individualizados y que aporten beneficios en general por su consumo. Todo esto se ha producido por la preocupación de su salud y de su apariencia física (Aina Centro Tecnológico, 2016). Las personas además de exigir y querer consumir productos naturales, sin preservantes, quieren saber dónde, cómo y quiénes han elaborado los productos que se consiguen normalmente en las tiendas de alimentos. Agregado a ello, los consumidores exigen que las empresas tengan un compromiso sostenible y ético con el medio ambiente. Es por ello que existe una necesidad por parte de los productores de alimentos, de reconocer los ingredientes, las cadenas de suministro, el método de producción y el desafío de generar un packaging ${ }^{1}$ amigable con el ambiente (Cornejo, 2017).

Actualmente son muchas las personas que se han empezado a informar sobre la composición nutricional de los productos que quieren comprar, debido a que tratan de cuidar su cuerpo leyendo las etiquetas nutricionales antes de adquirir un producto. Se puede observar así, la subordinación de los clientes hacia los fabricantes de los alimentos. Esto se genera debido a que los productores son los que elaboran los etiquetados con el contenido nutricional, regulados por las entidades, y todo esto puede afectar la impresión y la decisión de adquisición de los usuarios (Ducrot, 2016).

\footnotetext{
${ }^{1}$ Empaquetado
} 
Alvares Blanco (2011) indica que el factor que más influye en un 58\% en la toma de decisión de los consumidores es la imagen visual, ya que es suficiente con ver un plato de comida que parezca saludable para que aumenten los niveles de grelina - hormona del hambre - en el torrente sanguíneo y que surja la necesidad de comer. Estos hechos indican que los consumidores son fácilmente influenciables por la apariencia e imagen visual de los productos.

Ahora los clientes están indagando formas más veloces de consumir los productos recién hechos. Es por ello que el consumidor desea obtener mayor información sobre los productos, esto genera mayor confianza en los productos que guardan conexión con el pasado, como son los productos familiares o de los que tienen referencia por alguna persona que ellos conozcan (Pérez, 2017).

\subsubsection{Etiquetado de alimentos}

Los productos alimenticios deben tener etiquetas back of pack ${ }^{2}$ con todo el contenido nutricional en base de 100 gr o $100 \mathrm{ml}$ de alimentos, además de la lista de ingredientes y el índice de $\mathrm{GDA}^{3}$ (MINSA, 2012). Sin embargo, se necesita más que solo eso para lograr orientar al consumidor a fin de que pueda mejorar en sus decisiones de compra respecto a los productos saludables (Huerta, 2016).

Espinoza, Luna y Morán (2016) afirman que la mayoría de personas no entienden la información que se les brinda en los productos, ya que son nombres químicos que muchas personas desconocen. Dentro de la lista de componentes es muy difícil saber cuál es un componente perjudicial o beneficioso para la salud; además no todas las personas se toman el tiempo de leer las letras pequeñas que es como están descritos estos ingredientes. Es por ello que con toda la creciente demanda y oferta en el mercado de los alimentos, el Gobierno en conjunto con las asociaciones no gubernamentales e industrias de alimentos, han centrado su trabajo a la revisión, desarrollo y aplicación de diversos sistemas de información (guías nutricionales) para los usuarios. Esto ha llevado a crear el front of pack ${ }^{4}$, el cual busca dar al consumidor la información de manera más rápida y

\footnotetext{
2 Etiquetado en la parte trasera

${ }^{3}$ Guideline Daily Amount- Cantidades Diarias Orientativas

${ }^{4}$ Etiquetado frontal
} 
simple (Huerta, 2016). Wansink y Van Ittersym (2004) comentan que la información nutricional, comúnmente colocada en la parte posterior o lados colaterales de los productos, se entiende mucho mejor gracias a la información resumida y simplificada, que aparece en el front of package, sobre los nutrientes que podrían ser consumidos de manera excesiva por el cliente (azúcar, grasa, sodio). El etiquetado de alimentos es un derecho para las personas y una obligación de las empresas hacia los consumidores (cienciAmerica, 2017).

\subsubsection{Educación sobre los etiquetados y la obesidad infantil}

La mayor parte de los compradores no entienden lo que leen en el etiquetado nutricional, ya que muchos productos usan términos que son inusuales para ellos; todo esto afecta las elecciones alimenticias, lo que los lleva a tomar una decisión errada (Grunert et al., 2010). Rotfeld (2009) comenta que muchas personas no tienen conocimiento acerca de estos temas, y esto hace que se produzca una fase, en la cual aquellas personas que conocen acerca del tema, comprenden lo que leen, prestando mayor interés por ver los etiquetados y aplicar esto en sus decisiones, mientras los que no, continúan consumiendo productos dañinos para el cuerpo.

El desconocimiento del etiquetado es uno de los motivos por los que la sociedad no se alimenta correctamente (Organización de las Naciones Unidas para la Alimentación y la Agricultura, 2011). La relevancia de la información entregada por el etiquetado debe de ser clara y precisa. Muy pocas personas leen las etiquetas de lo que consumen: de acuerdo con la consultora Kantar World Panel, cuatro de cada cinco peruanos no leen nunca las etiquetas o lo hacen rara vez o de manera ocasional, porque simplemente no las entienden (El Comercio, 2017).

De otro lado, según Kain, Corvalán, Lera, Galán, Weisstaub y Uauy (2011), la obesidad está aumentando notablemente en países industrializados como en los del tercer mundo. En la etapa escolar los niños empiezan a exceder su $\mathrm{IMC}^{5}$ entre un 0,59 a 0,71. En Chile se observó que para prevenir la obesidad infantil se debería comenzar a educar

\footnotetext{
5 Índice de masa corporal
} 
sobre la nutrición tempranamente, en forma ideal desde los dos años (Kain, et al., 2011).

\subsubsection{Tipos de etiquetados}

Alrededor del mundo existen varias opciones de etiquetados nutricionales. A continuación se presentarán cuatro tipos de etiquetas que se mostrarán en este estudio: el etiquetado semáforo nutricional, el etiquetado de octógonos, el etiquetado canadiense y el etiquetado australiano (estrellas).

\subsubsection{Semáforo nutricional}

El Grupo de Prevención Coronaria de Reino Unido, en el año 1980, propuso un enfoque que precisaba los niveles "altos", "medios" y "bajos" de los principales elementos nutricionales en las comidas (grasas, azúcares y sal). La idea fue utilizada por algunas industrias de alimentos, principalmente fue adoptada por los supermercados para los alimentos de su propia marca. Sin embargo, el etiquetado nutricional simple (ver Ilustración 1) no fue avalado por la mayoría de los empresas durante gran parte de los años 90 (Espinosa et al., 2016). No obstante, debido a todas la inquietudes existentes por el incremento de los índices de obesidad y enfermedades causadas por la mala nutrición, como la alta ingesta de comestibles procesados y "listos para comer". En el 2004 el Gobierno de Reino Unido presentó un documento oficial nombrado "Choosing Health", el cual incitaba la instauración de un etiquetado frontal y más amigable con los consumidores, con el fin de este pudiera ser aplicado en los productos. En consecuencia, la FDA ${ }^{6}$ publicó una propuesta de etiquetado denominada Semáforo Nutricional, la cual utilizaba códigos de color para segmentar a los alimentos con "bajo", "medio" y "alto" contenido de nutrientes específicos como "grasa saturada", "azúcar" y "sal” (Espinosa et al., 2016). El Consejo de la FDA junto con los productores de alimentos y las cadenas de supermercados acordaron que el modelo de este etiquetado debía de seguir las siguientes características: 1) Brindar información detallada de cada elemento nutricional ("grasa", “grasa saturada", “azúcar” y "sal”); 2) Usar los colores "rojo", "ámbar” y "verde” para segmentar los niveles de los nutrientes de forma aislada; 3) Emplear los criterios nutricionales brindados por la FDA para asignar el color en cada producto; d) Señalar la

\footnotetext{
${ }^{6}$ Food Standards Agency
} 
información nutricional de cada nutriente por porción individual de producto (Espinosa et al., 2016).

Siempre han habido diversas discusiones por parte de las industrias alimentarias, los usuarios y el Parlamento Europeo, ya que sugieren que este tipo de etiqueta influye negativamente en la comercialización de los productos. Esto se da, debido a que genera interpretaciones negativas especialmente en las etiquetas "rojas", ya que productos etiquetados como sanos, como el aceite de girasol, poseen etiquetas "rojas" para "grasa y grasa saturada" (Instituto Nacional de Salud Pública de México, 2013). La Unión Europea (UE) rechazó la etiqueta nutricional propuesta por el Reino Unido, ya que expuso que no entendían como era que la gaseosa "light" tenía un etiquetado de color "verde" y el aceite de oliva extra virgen una etiqueta de color "rojo". Se comentó que existía una violación del principio fundamental de la libre circulación de mercancías de la Unión Europea, ya que se consideraba que el Gobierno estaba de manera ilegal interponiéndose en las decisiones de los consumidores (Instituto Nacional de Salud Pública de México, 2013).

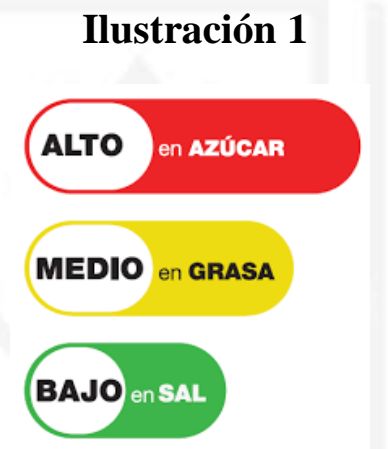

FUENTE: ANFAB

\subsubsection{Etiquetado octogonal}

En Chile, se ha propuesto el uso de octógonos en los empaques (ver Ilustración 2). Estas etiquetas tiene la forma de un octágono negro con la frase "ALTO EN" en el medio del mismo. Con ellos se notifica la cantidad desmedida de "azúcar", "grasas saturadas", "sodio" o "calorías" del producto, para dictaminar si es que el alimento debe de tener la etiqueta octogonal. Se observa la cantidad del elemento en 100 gramos o en 100 mililitros, determinados por el Ministerio de Salud. Es por ello, que un alimento podría tener entre cero y cuatro octógonos (uno por cada elemento nutricional). Con esta herramienta se quiere informar que los contenidos de ciertos productos superan la 
cantidad óptima de nutrientes que un alimento debería de tener, y es por ello que su consumo debe de ser medido, ya que es perjudicial para la salud (Ministerio de Salud Chile, 2016).

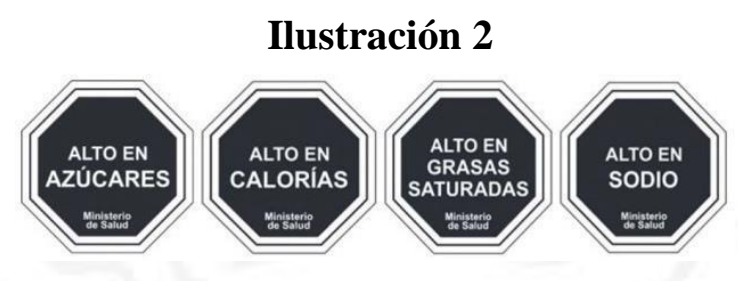

\section{Fuente: Ministerio de Salud del Perú}

\subsubsection{Propuesta de etiquetado canadiense}

En Canadá, las cifras de sobrepeso u obesidad oscilan entre 16,9\% y 6,2\% en jóvenes y $36,80 \%$ y 25,1\% en adultos (Canadian Food Inspection Agency, 2018). Es por ello que el Ministerio de Salud Canadiense apuesta por un sistema de etiquetado con símbolos parecidos a los que implementó Chile en el 2016, queriendo así etiquetar con un aviso los alimentos con un alto contenido en "azúcar", "grasa" o "sodio" con una alerta especial para reducir su consumo (CBC Radio Canada, 2018). La Ministra de Sanidad, Ginette Petitpas Taylor, comentó que el objetivo es "que elegir la opción saludable sea lo más fácil" (CBC RadioCanada, 2018). Con esta medida, cualquier producto que tenga más del 15\% de "azúcar", "sodio" o "grasas saturadas" por porción de la ingesta diaria recomendada, tendrá un sello (CBC Radio-Canada, 2018). No todos los productos serán etiquetados de la misma manera; habrá excepciones para algunos productos, como la leche entera y semidesnatada, y productos que obviamente sobrepasan ese límite, como los paquetes de sal o azúcar, la miel o el sirope de arce. Por otro lado, no deberán etiquetarse con la alerta, los productos que tengan endulzantes de alta intensidad como el aspartame ${ }^{7}$, la sucralosa ${ }^{8}$, el acesulfamo- ${ }^{9}$ y el neotame ${ }^{10}$ (Government of Canada, 2018). No obstante, la Ministra Petitpas cree que cerca de la mitad de los alimentos envasados necesitan de una de esas etiquetas (CBC Radio-Canada, 2018). Los objetivos del etiquetado $\mathrm{FOP}^{11}$ son proporcionar orientación rápida y fácil para alentar a las personas a reflexionar en sus decisiones sobre los alimentos en relación con sodio,

\footnotetext{
${ }^{7}$ Edulcorante dañino para la salud

${ }^{8}$ Edulcorante 600 veces más dulce que el azúcar

${ }^{9}$ Edulcorante artificial

${ }^{10}$ Edulcorante 8000 veces más dulce que azúcar

${ }^{11}$ Front of package
} 
azúcares y grasas saturadas; y fomentar la disponibilidad de alimentos bajos en estos nutrientes, reduciendo así los riesgos para la salud (Government of Canada, 2018).

El gobierno canadiense ha propuesto cuatro tipos de etiquetados (ver Ilustración 3), con el fin de que la población pueda elegir cuál de estos es más fácil de comprender. Una vez decidida cuál es la mejor etiqueta, los fabricantes tendrán hasta el 2022 para bien implementarla en sus productos o bien reducir la cantidad de azúcar, sodio o grasas saturadas (Canadian Food Inspection Agency, 2018). Sin embargo, algunas asociaciones de médicos afirman que no se está yendo lo suficientemente lejos para salvaguardar la salud de los consumidores: "El signo de exclamación o la lupa no tienen el mismo impacto que hubiera tenido un símbolo de stop en color negro", afirmó el doctor Yoni Freedhoff, del Bariatric Medical Institute, haciendo referencia a una propuesta que no pasó de las primeras reuniones (CBC Radio-Canada, 2018).

\section{Ilustración 3}

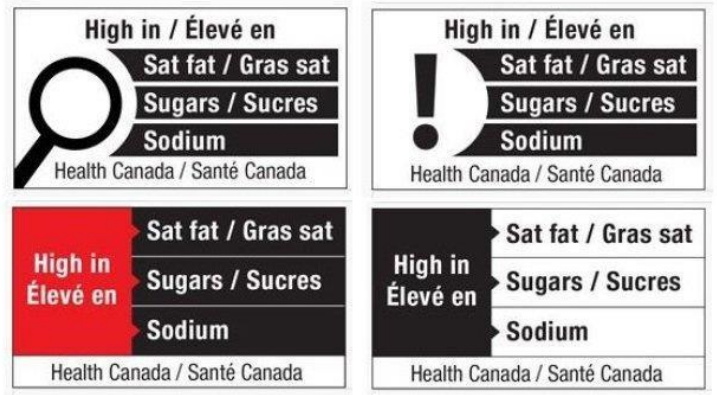

Fuente: Gobierno de Canadá (2018)

\subsubsection{Etiquetado de estrellas (Australia y Nueva Zelanda)}

La industria alimentaria siempre se ha negado a que sus productos sean categorizados según su contenido en "grasas", "azúcares", "sal”, "fibra" y "aporte calórico", pero los Gobiernos de Australia y Nueva Zelanda se decidieron llevar adelante un etiquetado diferente, a pesar de la gran presión que se ha ejercido por parte de la industria alimentaria (Australian Institute of Food Safety, 2014). Se consideró que era necesario un nuevo tipo de etiquetado para poder contribuir a los consumidores a que tomen decisiones más sanas. Es por ello que se creó el etiquetado de estrellas (ver Ilustración 4), que califica a los productos según el número de estrellas que tengan: cuantas más estrellas tiene un alimento, es más saludable, ya que ha obtenido mejor calificación en los cálculos del algoritmo que fueron realizados al tener en cuenta el contenido nutricional del producto. Este algoritmo se diseñó centrándose en los estándares alimentarios de Australia y Nueva Zelanda (Burgue, 2014). 
El etiquetado de estrellas entró en vigencia el 13 de Diciembre del 2014, como el reglamento (UE) No 1169/2011 (Food Standards Australia New Zeland, 2013). Al principio no era obligatorio y se tuvo que contar con un periodo de cinco años para introducirlo de manera correcta. Además, la industria alimentaria argumentó que este tipo de etiquetado era confuso y que provocaba un incremento del precio de los productos. Sin embargo, este tuvo como objetivo principal generar un alto nivel en el cuidado de la salud de las personas y resguardar su derecho a la información. Con este reglamento se simplificó y estandarizó la normativa, se garantizó la seguridad jurídica, se disminuyeron las cargas burocráticas y se favorecieron los intereses de los consumidores, ya que se estableció el deber de etiquetar los productos de manera simple y entendible; además se intentó evitar acciones y omisiones de información engañosa (Betelgeux, 2015). Esto se hizo con el fin de que los consumidores australianos pudieran observar cómo algunos productos que normalmente consumen, poseen un sistema que brinda la información de manera sencilla de entender y ayuda a generar una elección de los alimentos más adecuados para una alimentación balanceada. Junto al lanzamiento del etiquetado de alimentos por estrellas, se puso en marcha una campaña promocional que enseñó a los consumidores cómo funcionaba el nuevo sistema de etiquetado y solucionaba cualquier duda que se pudieran plantear (Health Star Rating System, 2015).

Todo esto llevó a que varias asociaciones de consumidores pidieran a la industria alimentaria que introduzca cuanto antes el nuevo etiquetado (Ilustración 4), dado el problema de sobrepeso y obesidad existente en el país. Grandes empresas, como la cadena de supermercados Woolworths, se manifestaron implementando el sistema en sus productos, adelantándose ante sus competidores y mostrando que querían contribuir a mejorar la alimentación de la población (Health Star Rating System, 2015).

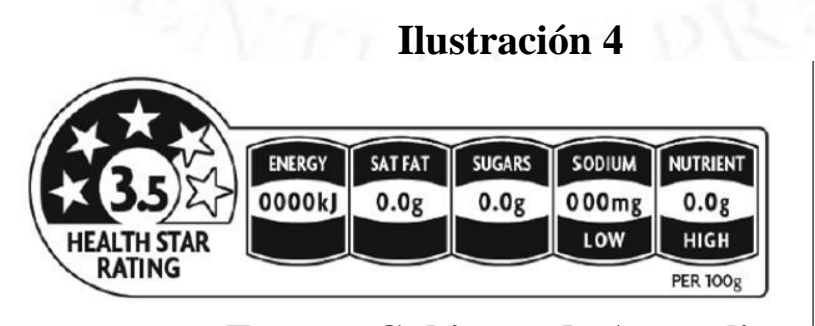

Fuente: Gobierno de Australia 


\subsection{Regulación}

El semáforo nutricional fue adoptado posteriormente por Ecuador y aprobado en Bolivia (OPS Bolivia, 2016). Por su parte, México utilizó un sistema de etiquetado frontal en el 2015, el cual reguló los contenidos y el horario de la publicidad de los productos dañinos. Sin embargo, el país que supo llevar mejor la regulación de los etiquetados nutricionales fue Chile, esta regulación se llamó la "Ley de Composición Nutricional de los Alimentos y la Restricción de Publicidad", entrando en vigencia el 27 de julio del 2016 (Cornejo, 2017).

\subsubsection{Regulación en Chile}

En Chile desde el año 2006 se empezó a discutir sobre la ley del etiquetado de alimentos, una discusión que duró 10 años. Finalmente en el 2016, decidieron instaurar la ley del etiquetado en el país. La preocupación del Gobierno de Chile empezó, ya que se dieron cuenta que la mayor parte de sus ciudadanos sufrían problemas de salud, debido a su sobrepeso, tanto personas mayores como niños. En el año 2009, más del 60\% de la población cuya edad oscilaba entre los 15 a 64 años de edad, tenía obesidad o exceso de peso. Esto fue alarmante para el Gobierno, debido a que en 1987, el 7\% de los estudiantes de primaria eran obesos, mientras que en el 2016, esa cifra aumentó a 24,6\% (Organización Panamericana de la Salud/Organización Mundial de la Salud, 2016). Chile lidera las cifras en el consumo de bebidas azucaradas, siendo el segundo país de Latinoamérica con la mayor venta de gaseosas (Organización Mundial de la Salud, 2016).

La Ley de Alimentos se aplicó con los cambios introducidos en el 2015 al Reglamento Sanitario de los Alimentos, que se establecía en la norma y los límites permitidos de contenido de "sodio", "calorías", "grasas saturadas" y "azúcares" por 100 gr, en alimentos sólidos, o por $100 \mathrm{ml}$, en alimentos líquidos. Sobre la base de esta información, se aplican las nuevas etiquetas y las prohibiciones de venta y publicidad. Empezaron introduciendo estos límites máximos de forma progresiva, con el objetivo de lograr disminuir la cantidad de calorías y componentes perjudiciales de los alimentos hasta obtener los límites permitidos. Se consideraba que si se hacía abruptamente, no 
funcionaría como se esperaba; además se buscaba darle tiempo a las empresas de poder transformar sus productos y modificarlos según como lo indicaba la ley (Organización de las Naciones Unidas para la Alimentación y la Agricultura, 2017).

Para propagar este régimen, se realizó una campaña masiva con anuncios publicitarios. Con esta ley se el principal objetivo fue posicionar la etiqueta de advertencia "ALTO EN", que brindaba la información para seleccionar y facilitar la adquisición de productos más sanos; además, otro de los objetivos fundamentales de esta campaña fue poder difundir la prohibición de productos perjudiciales en los establecimientos de educación (Cornejo, 2017).

Chile es un gran ejemplo, ya que fue el primer país en el mundo en dictaminar la ley que regula simultáneamente tres medidas que colaboran a aminorar la obesidad y a acrecentar la ingesta de alimentos saludables: "la etiqueta frontal de prevención", "las limitaciones a las propagandas destinadas a menores de catorce años de edad", y "la prohibición del expendio de productos dañinos en los colegios y sectores aledaños a este". Estas tres regulaciones son apoyadas por la FAO y la OPS/OMS para prevenir el exceso de peso entre los menores (Organización de las Naciones Unidas para la Alimentación y la Agricultura y Organización Panamericana de la Salud, 2017).

Para evaluar la Ley, se realizó la "Encuesta Nueva Ley de Etiquetado de Alimentos" por Demoscópica junto con ICEI de la Universidad de Chile, a pedido del Ministerio de Salud (MINSAL) de Chile, a 1067 personas dentro de las 34 comunas que conforman Santiago. Se tomó como muestra, personas de los sectores socioeconómicos desde A hasta E. En ésta se pudo determinar que la muestra reconocía los sellos de advertencia "ALTOS EN", y más del 90\% de estos, consideraron como "bien" o "muy bien" la instauración de las etiquetas frontales de advertencia "ALTO EN" en los productos e indicaron que estaban de acuerdo con la prohibición de venta de productos dañinos dentro de las escuelas. Por otro lado, el 75\% de la muestra consideró positiva la negativa de la propaganda de los alimentos dañinos, dirigida a los niños (Demoscópica y Universidad de Chile, 2017). 
Se pudo concluir que si bien los encuestados señalaban que las etiquetas de advertencia influían en sus decisiones de consumo, aún se observaban dificultades en la capacidad de reconocimiento y estimación en las disposiciones de etiqueta y su poder de influencia en la adquisición de productos. Chile, gracias a esto, tuvo que seguir creando campañas de concientización hasta conseguir que su población modifique sus hábitos de consumo en productos procesados. La primera etapa en la que se trabajó fue la de brindar información más clara y concisa, enfocada en los grupos que no conocían la norma y sus consecuencias, y a los otros grupos como niños, personas con obesidad, enfermedades crónicas, entre otras con enfermedades similares. (Demoscópica y Universidad de Chile, 2017).

Con los esfuerzos anteriores, la Ley se instauró con las tres medidas regulatorias, de esta forma ningún producto que tenga un etiquetado de "ALTO EN" puede sobrepasar los límites máximos señalados por la norma, tampoco pueden promocionar sus productos en colegios ni entornos cercanos a este, ni realizar propaganda que se dirija a menores de catorce años. Los límites dictaminan 100 gr para productos sólidos y $100 \mathrm{ml}$ para los líquidos, esto con el fin de prevenir las confusiones que se hubiesen generado si se hubieran establecido los límites por clase de alimento o por tamaño de producto (MINSAL, 2016). El impulso que ayudó a lograr la correcta implementación de la Ley, fue la gran preocupación de las autoridades gubernamentales por encontrar una rápida solución a las dificultades y enfermedades relacionadas con el sobrepeso en el país, además de la ayuda que se recibió en la recopilación y difusión de información que justificaba la aprobación de la Ley, por parte de diversas organizaciones y universidades en todas las etapas que se llevaron en el proceso de aplicación de la normativa (Universidad de Chile, 2017).

Asimismo, la Universidad de Carolina del Norte (Programa de Investigación en Alimentos) de EE.UU, ), la Universidad Diego Portales (Facultad de Comunicación) y la la Universidad de Chile (INTA). evaluaron los primeros efectos que tuvo la ley de etiquetado de alimentos en Chile entre los 6 y 10 primeros meses después de su implementación (Universidad de Chile, 2017). Se vio que hubo una disminución en la exposición de anuncios de productos dañinos en un $46 \%$ en los preescolares y en un $62 \%$ en los adolescentes. Agregado a ello, se tuvo una reducción en el consumo promedio de sodio y azúcares en un $50 \%$ en alimentos envasados; además que los consumidores 
reconocen mejor la cualidad nutricional de los productos envasados después de la implementación de etiquetas de advertencia, ya que tanto las madres de familia y los adolescentes estudiados, valoran los sellos y los utilizan para saber qué tan saludable es un producto.

Por último, se obtuvo una reducción en las compras de bebidas y cereales "altos en" en los hogares, ya que hubo una reducción en la compra de cereales en un $14 \%$, mientras que en los bebestibles, considerando que algunos productos han cambiado sus ingredientes debido a la ley, se ha disminuido su consumo en un $25 \%$. Todo esto lleva a pensar que las personas, particularmente los niños, han ido mejorando su alimentación y su preocupación por la salud (Universidad de Chile, 2018).

\subsubsection{Regulación en el Perú}

En el Perú hubo mucha discusión sobre qué etiquetado era mejor instaurar, si el etiquetado semáforo o el etiquetado con polígonos. Gastón Ares (2016), catedrático de la Universidad de la República de Uruguay, considera que el etiquetado de octógonos es más eficiente para poder generar cambios de hábitos en las personas.

La Ley N 30021 es la Ley de promoción de la alimentación saludable para niños, niñas y adolescentes. "Ésta dispuso la difusión y el resguardo efectivo del derecho a la salud pública, al crecimiento y desarrollo adecuado de las personas, a través de las acciones de educación y fomento de la actividad física, implementación de kioskos y comedores saludables en las instituciones de educación"(Ley N 30021, 2013). Agregado a ello, se supervisará la publicidad relacionada con alimentos y bebidas no alcohólicas dirigidas a los niños y adolescentes. Con esto se busca reducir y eliminar las enfermedades crónicas vinculadas al sobrepeso y obesidad. Se estableció que todos los alimentos procesados deben llevar etiquetas de advertencias publicitarias (El Peruano, 2018). 
La controversial Ley de Promoción de Alimentación Saludable intentó entrar en vigencia desde el 2014, y en el 2018 ésta se impulsó con especial esfuerzo (Gómez, 2018). Se estima que en el Perú el porcentaje de la población que suele leer los etiquetados nutricionales es inferior en cotejo con otros países; a pesar de ello diversos estudios, que serán mencionados posteriormente sobre los hábitos del consumidor, han evidenciado que el interés de las personas por su salud y apariencia, aumenta su atracción por revisar la información nutricional en los empaques. De esta manera logran estar mejor informados, satisfacen su necesidad de alimentación y protegen su salud y a su familia (La Nación, 2018). Las madres de menores, nutricionistas y deportistas profesionales lideran los grupos que revisan los etiquetados nutricionales antes de adquirir un producto (La Nación, 2018).

Se realizó una investigación por Comebien (2018), que es una plataforma de información al consumidor, creada por Molitalia, Alicorp, Nutritiva y Laive. Ellos contrataron a Arellano Marketing para realizar un estudio preliminar que les permitiera saber qué es lo que realmente piensa el consumidor sobre el etiquetado semáforo y el octogonal, ya que estas propuestas estaban siendo debatidas en el Congreso. Se tomó como muestra a 200 mujeres madres de familia, las cuales tomaban las decisiones de compra de productos en sus hogares, intercalando entre las conservadoras y modernas. Sus principales hallazgos: 66\% consideró que el etiquetado semáforo (GDA) es más informativo, 55\% dijo es más fácil de entender y el $61 \%$ le encontraba mayor utilidad en la toma de decisiones.

Se pudo concluir con esto además, que a pesar de que lo más criticado del etiquetado semáforo es su complejidad, la mayor parte de las encuestadas lo encontraron más sencillo de recordar y de comprender. El octágono, por otro lado, fue catalogado por la muestra como una opción que "podría entender un niño", ya que es súper sencillo de comprender (Comebien, 2018). El principal responsable de que no se logre cambiar los hábitos alimenticios en el Perú es la desinformación, ya que se encontró en esta investigación que la mayoría de las encuestadas no tenían conocimiento acerca de los términos nutricionales.

Otro estudio fue a pedido de la Sociedad Nacional de Industrias, con el que se pudo observar que el $67 \%$ de los consumidores prefieren el etiquetado semáforo para sus 
alimentos y bebidas. Este fue realizado por la Compañía Peruana de Investigación de Mercados y Opinión Pública SAC en base a mil personas (mayores de edad) provenientes de 25 ciudades del Perú. El objetivo fue conocer si los peruanos realmente leen las etiquetas antes de comprar y determinar qué modelo de etiquetado preferirían.

Según la encuesta, se preferiría este tipo de etiquetado frente al "sello de advertencia" (19\%), pues se entiende mejor (70\%) y brinda más información $(69 \%)$. Asimismo, aseguran que el $87 \%$ de los peruanos, sin distinción de lugar o edad, ha leído al menos una etiqueta de los alimentos o bebidas que consumen. Lo que los consumidores suelen revisar es: fecha de vencimiento, lista de ingredientes y nombre de los alimentos (Sociedad Nacional de Industrias, 2017).

Por otro lado, Liliana Alvarado y José Ignacio Beteta (2018) realizaron un estudio de neuromarketing, para medir la respuesta cerebral de los consumidores peruanos en respuesta a las opciones de etiquetado nutricional. Se concluyó que el modelo del Semáforo Nutricional es más atractivo visualmente, genera mayor retención de atención y mejor comprensión que el etiquetado octogonal, el cual genera rechazo al consumo de productos dañinos. "Se observó que el Semáforo Nutricional genera mayor tiempo de atención, exploración visual y retención (2.08 segundos promedio) versus el tiempo de observación del Octógono (1.52 segundos). En cuanto al tiempo de detección de la advertencia, a los consumidores les tomó menos tiempo detectar el semáforo (1.57 segundos) versus el octógono (2.2 segundos). El Semáforo Nutricional también resulta mejor en términos del número de visitas que obtiene el área de información nutricional, 7 visitas del formato Semáforo versus 5.6 visitas en las etiquetas con Octógono" (Diario Gestión, 2018, párr. 06).

Asimismo, el Ministerio de Salud en el 2018, llevo a cabo un estudio para la elaboración del Manual de Advertencia Publicitaria en el Perú. El estudio se hizo con el objetivo de conseguir información respecto a las percepciones de la muestra sobre la relación de la salud y la alimentación, y elementos como el contenido, colores y formas que deben de tomarse en cuenta en las advertencias publicitarias. Además, de conocer cuáles elementos son de mejor comprensión y aceptación por las personas. En el estudio participaron adolescentes y padres de familia de centros educativos de Lima, Trujillo, Cusco y Tarapoto. El Manual de Advertencias Publicitarias, que rige las normas para el 
etiquetado nutricional en el Perú, utilizó como guía los hallazgos de este estudio, en ellos se destacó la desinformación de la Ley No 30021, ley que regula el uso de etiquetados nutricionales en el Perú, y el reconocimiento de la estimación de tener mensajes de prevención sobre los elementos dañinos en el cuerpo (El Peruano, 2018).

El 16 de junio del 2018 el Poder Ejecutivo aprobó el uso de octógonos en los productos de consumo no saludables, como parte del Manual de Advertencias de Alimentos Procesados en donde se detallan qué pautas se deben tener en cuenta frente a las advertencias en los productos altos en sodio, azúcar y grasas saturadas, como parte de la implementación de la Ley de Alimentación Saludable (El Peruano, 2018). Esta ley se implementó en Junio del 2019, ya que se acordó que entraría en vigencia a los doce meses desde que se aprobó, contados a partir del domingo 18 de Junio (El Peruano, 2018).

Los parámetros indicados para la regulación de la ley del etiquetado nutricional, se han dado de forma progresiva, debido a que se les ha brindado un plazo máximo de 39 meses a las empresas para que puedan modificar la elaboración de sus productos, sin verse afectados. Se puede ver en el siguiente cuadro cómo es que el Estado ha regulado los plazos de la ley:

\section{Ilustración 5}

\begin{tabular}{|c|c|c|}
\hline \multirow[b]{2}{*}{$\begin{array}{l}\text { Parámetros } \\
\text { técnicos }\end{array}$} & \multicolumn{2}{|c|}{ Plazo de entrada en vigencia } \\
\hline & $\begin{array}{c}\text { A los } 6 \text { meses de aprobación } \\
\text { del Manual de Advertencias } \\
\text { Publicitarias }\end{array}$ & $\begin{array}{l}\text { A los } 39 \text { meses de } \\
\text { aprobación del Manual de } \\
\text { Advertencias Publicitarias }\end{array}$ \\
\hline $\begin{array}{l}\text { Sodio } \\
\text { en alimentos } \\
\text { sólidos }\end{array}$ & Mayor o igual a $800 \mathrm{mg} / 100 \mathrm{~g}$ & Mlayor o igual a $400 \mathrm{mg} / 100 \mathrm{~g}$ \\
\hline $\begin{array}{c}\text { Sodio } \\
\text { en bebidas }\end{array}$ & $\begin{array}{l}\text { Mayor o igual a } 100 \mathrm{mg} / \\
100 \mathrm{ml}\end{array}$ & $\begin{array}{l}\text { Mayor o igual a } 100 \mathrm{mg} / \\
100 \mathrm{ml}\end{array}$ \\
\hline $\begin{array}{l}\text { Azúcar Total } \\
\text { en alimentos } \\
\text { sólidos }\end{array}$ & Mayor o igual a $22.5 \mathrm{~g} / 100 \mathrm{~g}$ & Mayor o igual a $10 \mathrm{~g} / 100 \mathrm{~g}$ \\
\hline $\begin{array}{l}\text { Azúcar Total } \\
\text { en bebidas }\end{array}$ & Mayor o igual a $6 \mathrm{~g} / 100 \mathrm{ml}$ & Mayor o igual a $5 \mathrm{~g} / 100 \mathrm{ml}$ \\
\hline $\begin{array}{c}\text { Grasas } \\
\text { Saturadas } \\
\text { en alimentos } \\
\text { sólidos }\end{array}$ & Mayor o igual a $6 \mathrm{~g} / 100 \mathrm{~g}$ & Mayor o igual a $4 \mathrm{~g} / 100 \mathrm{~g}$ \\
\hline $\begin{array}{c}\text { Grasas } \\
\text { Saturadas } \\
\text { en bebidas }\end{array}$ & Mayor o igual a $3 \mathrm{~g} / 100 \mathrm{ml}$ & Mayor o igual a $3 \mathrm{~g} / 100 \mathrm{ml}$ \\
\hline Grasas Trans & Según la normatividad vigente & Según la normatividad vigente \\
\hline
\end{tabular}

Fuente: Artículo 4 del Decreto Supremo N ${ }^{\circ}$ 017-2017-SA. 


\section{Fuente: El Peruano}

Los octógonos deben de seguir el siguiente formato:

- Color: negro y blanco.

- Tipografía: Helvética LT Std-Bold

- Forma geométrica: Octógono.

Según la normativa, si es que el producto posee más de dos advertencias de “ALTO EN", éste debe llevar una leyenda que diga "evitar su consumo en exceso", tal como se muestra en la ilustración 7; pero si es que el producto contiene sólo la etiqueta de "grasas trans" también debe llevar la leyenda: "evitar su consumo en exceso". El tamaño de estas etiquetas se dará de la siguiente manera (Ilustración 6):

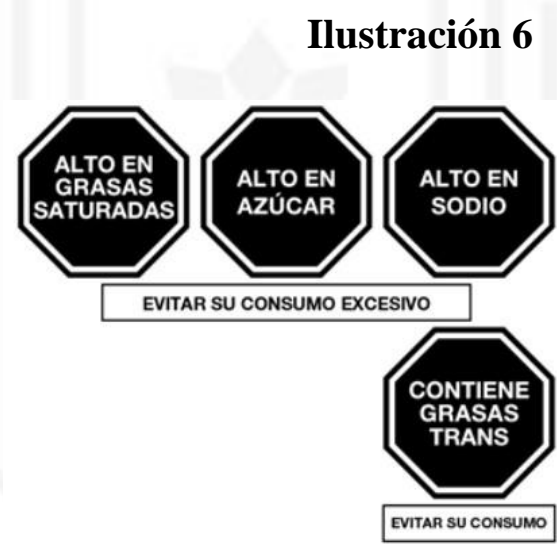

Fuente: El Peruano

\section{Ilustración 7}

\begin{tabular}{|c|c|}
\hline $\begin{array}{c}\text { Área de la cara frontal } \\
\text { o principal de la etiqueta }\end{array}$ & $\begin{array}{c}\text { Tamaño de las } \\
\text { advertencias publicitarias }\end{array}$ \\
\hline Menor a $50 \mathrm{~cm}^{2}$ & $\begin{array}{c}3,0 \mathrm{~cm} \text { de ancho } \times 3.0 \mathrm{~cm} \text { de alto } \\
\text { (en la etiqueta del envase que contenga a } \\
\text { los productos) }\end{array}$ \\
\hline De 50 a menor $100 \mathrm{~cm}^{2}$ de área & $2,0 \mathrm{~cm}$ de ancho $\times 2.0 \mathrm{~cm}$ de alto \\
\hline De 100 a menor $200 \mathrm{~cm}^{2}$ de área & $2,5 \mathrm{~cm}$ de ancho $\times 2.5 \mathrm{~cm}$ de alto \\
\hline De $200 \mathrm{~cm}^{2}$ a más área & $3,0 \mathrm{~cm}$ de ancho $\times 3.0 \mathrm{~cm}$ de alto \\
\hline
\end{tabular}

Fuente: El Peruano 
La ley de alimentación saludable está compuesta por 11 artículos, de los cuales se pueden ver los más relevantes en el Anexo 1. Estos han sido considerados como los más importantes para la presente investigación. (Ver Anexo 1)

\section{3 ¿Qué dicen los estudios recientes sobre el uso de etiquetados? (2013 - 2018)}

El consumo de bebidas azucaradas ha incrementado los riesgos de obesidad, diabetes, problemas al corazón y caries (Organización Panamericana de la Salud, 2016). Las intervenciones para frenar esto se han hecho a través de restricciones en el marketing como se puede ver en el ejemplo de los paquetes de cigarrillos (Ilustración 8), que ha sido usado en países como México, Francia, Hungría y diferentes partes de Estados Unidos. Un gran número de estudios realizados en estos países demuestran que el marketing influye en gran porcentaje sobre las decisiones de los niños (Bollard, Maubach, Walker \& Ni Mhurchu, 2016).

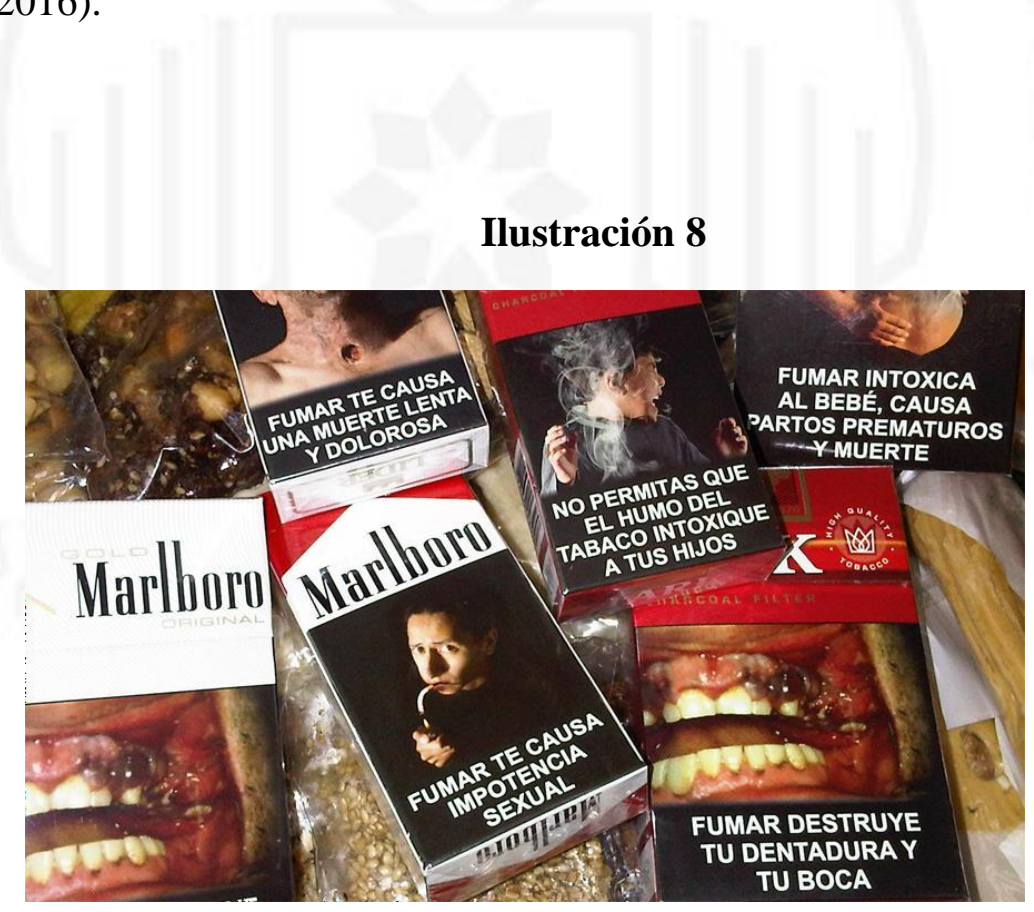

Nota: Recuperado de "Etiquetas en cajetillas de cigarro por Notimex", 2014. http://mundoejecutivoexpress.mx/salud/2014/09/23/nuevas-etiquetas-cajetillas-cigarros

Bollard, Maubach, Walker y Ni Mhurchu. (2016) realizaron una investigación online en Nueva Zelanda para poder descubrir los efectos del etiquetado. Las personas elegidas como muestra del estudio debían ser reportadas como consumidores de SSB 
(bebidas azucaradas), y las edades debían oscilar entre los 13 y 24 años. Se mostraron los empaques con una etiqueta de octógono naranja, la cual advertía sobre los altos niveles de azúcar, y además se mostraba un gráfico de caries parecidas a las imágenes que ponen en las cajas de tabaco. Unas 604 personas fueron estudiadas. Se demostró que las imágenes puestas en el empaquetado influían más que el texto. Este tipo de empaquetado hacía que las personas pensaran que el producto no era agradable, quitándole la calidad y dejando de creer que era bueno; además, este tipo de etiquetado generaba que los padres se dieran cuenta de lo dañino que era y ya no quisieran adquirirlo. Muchos participantes opinaron que sería mejor si se pusiera la imagen primero y después el texto para así poder causar mayor impacto (Bollard et al., 2016).

Un estudio realizado por Moens (2018) muestra cómo los países de la Unión Europea como Alemania, Francia e Italia utilizan las Guías de Alimentación (GDAs) con casillas de advertencias en los que se toman en cuenta cifras y porcentajes de “carbohidratos", "proteínas", “energía", "grasas", "fibra” y "sodio". Este estudio mostró que el uso de estas guías logró reducir en 19\% del consumo de azúcar en su población. Dentro de los estándares de información y etiquetado nutricional de la UE, se establece que se pueden implementar guías visuales como las del etiquetado semáforo. En este sentido, el Gobierno Británico todos los años realiza estudios para comprobar la eficiencia del etiquetado semáforo, demostrando que es efectivo en un 47\% (Moens, 2018).

George Institute (2016) realizó un estudio sobre el etiquetado de estrellas, haciendo un análisis de más de 34,000 productos y se descubrió que el sistema de calificación de estrellas se estaba poniendo correctamente en la mayoría de los productos. Sin embargo, el profesor Mark Lawrence (2017) de la Universidad de Deakin observó que el etiquetado de estrellas tiene algunos defectos importantes, ya que si se observan los nutrientes de forma aislada, estos representan erróneamente la tabla nutricional. Se encontró además, que poner estrellas de la salud en los alimentos, independientemente de si son alimentos saludables o comida chatarra directamente socava los mensajes en las directrices dietéticas australianas (ABC Australia, 2017).

Por otro lado, Consumers International (2015) realizó un estudio en donde les mostró a individuos de nueve países de Asia, África, América y Europa alimentos locales envasados "con” y "sin” etiquetado semáforo. Se les solicitó que clasificaran los 
alimentos por "altos", "medianos" o "bajos" en "sal”, "azúcar” y "grasas", y que seleccionaran la opción más sana en referencia a otros productos parecidos. Se observó que las personas que hicieron estimaciones precisas de los productos saludables se duplicó gracias a que el etiquetado nutricional frontal en el producto fue sencillo, ya que utilizaba los colores del semáforo. Se concluyó además, que cuando no se tiene una etiqueta sencilla, las personas consumen productos que podrían tener niveles dañinos para la salud en "grasa", "azúcar" y "sal”, lo que genera enfermedades y dolencias cardíacas, diabetes y cáncer. Es necesario tener e instaurar una etiqueta nutricional sencilla, frente al envase de los productos, ya que esta es la única manera que el Estado puede generar medidas preventivas que ayuden a la población a tomar decisiones más sanas (Consumers International, 2015).

Carissa (2016) realizó otro estudio acerca de la influencia del etiquetado en la percepción y elección del consumidor sobre sus alimentos y bebidas en Uruguay. Aquí se observó tanto el entorno como el individuo y alimento. Se descubrió que los padres para elegir los alimentos adecuados de sus hijos se basan primero en el diseño gráfico de estos. Éste debe ser atractivo visualmente y tener personajes infantiles, además de ciertos detalles como vitaminas y minerales. Observaron que mientras más grande sea el dibujo de la publicidad, los consumidores lo percibían como divertido queriendo comprarlo, además de que si el empaque contenía la palabra "fruta" se aumentaba la percepción de saludable y del valor nutricional de los alimentos. Carissa (2016) explicó que el etiquetado octogonal o de advertencias ayuda a reconocer en forma rápida los alimentos con contenido nutricional inadecuado, disminuyendo así la percepción de saludable en productos con perfil nutricional dañino, logrando mejorar la capacidad de los consumidores de identificar productos con perfiles malos, y restando la intención de compra y consumo. Se demostró también que el sistema octógono tiene influencia en las elecciones de los niños en los alimentos que consumen en la escuela (Carissa, 2016).

Todos los estudios mencionados anteriormente muestran la importancia e influencia que tiene el etiquetado nutricional en el consumidor, ya que éste ayuda a tomar mejores decisiones sobre los productos saludables y a entender qué componentes son dañinos para la salud de las personas. 


\section{CAPÍTULO 2: MARCO TEÓRICO}

En este capítulo se presentan dos modelos relevantes que ayudarán a entender el presente estudio: el Modelo Económico Racional y el Elaboration Likelihood Model, ya que en esta investigación, se analizará la percepción de los consumidores ante estos dos tipos de etiquetados.

\subsection{Modelo económico racional}

El hombre tiene la idea de que siempre suele tomar las decisiones correctas, dada su naturaleza humana. Además, tiene la noción de que la frecuencia con la que comete errores resulta ser desconocida para él, llevándolo a repetir el error una y otra vez sin tener la capacidad de entender el error bajo su propia experiencia (Naranjo, 2016).

El modelo económico racional sugiere la idea de que las personas por su naturaleza humana creen que siempre toman las decisiones correctas por ellas mismas (Ariely, 2013). Esta irracionalidad es lo que dificulta al hombre en el momento de tomar las decisiones correctas, cuando éste se encuentra frente a una cantidad de opciones diferentes en su entorno. Además, las personas cuentan con una memoria de capacidad limitada por lo que tienen muy poca información acerca de lo que se va a decidir y cierta o escasa incertidumbre de las consecuencias de sus actos (Ariely, 2013).

Cuando el ser humano debe decidir entre dos opciones, establece una comparación entre los objetos por los que debe decidir; si se le ofrece un atributo adicional en uno de ellos, el hombre presupone que es mejor, ya que éste le entrega una característica diferente a lo tradicional (Kahneman \& Tversky, 1973). La mente humana opera de forma paradójica, puesto que actúa dirigida bajo estímulos y atajos mentales (heurísticos). Las ideas que primarán frente a las decisiones del hombre se basarán ampliamente en analogías visuales, ya que lo que importa es la intuición y en ésta finalmente se basarán los juicios y elecciones (Kahneman \& Tversky, 1973). 


\subsubsection{Heurísticos:}

Los heurísticos son reglas que nuestra mente sigue de manera inconsciente para poder simplificar un problema, y así poder resolverlo fácilmente. Gracias a estos atajos mentales, se puede encontrar una respuesta rápida a una pregunta compleja (Kahneman, 2011).

Naranjo (2016) realizó una investigación sobre la percepción de los consumidores hacia las bebidas light, y para ello utilizó el modelo económico racional. Con éste entendió que sólo algunas personas examinaban la fecha de vencimiento y ocasionalmente el contenido energético, grasas o el término "light". Esto se dio debido a que cierta parte de la muestra, al ver términos como "bajo en grasa", "bajo en calorías" o "light", no generaban ninguna reacción, ya que no representaban nada para ellos, llevándolos a ser indiferentes a los etiquetados mencionados. En contraste, la otra parte de la muestra al ver que el etiquetado les ofrecía un atributo adicional, que son los términos "light”, "bajo en grasa", "bajo en calorías", presuponían que era mejor, ya que éste les entregaba una característica diferente a lo tradicional. Esto demostraba que el etiquetado de alimentos ayudaba a cierto grupo de personas a tomar mejores decisiones en su dieta y estilo de vida.

Naranjo (2016) confirmó en su estudio que las personas hacen caso al uso de heurísticos o atajos mentales para tomar decisiones, debido a que los sujetos enfrentan ambientes dinámicos que degradan su racionalidad, siendo ésta afectada por la emocionalidad. Además, los resultados del estudio de Naranjo demuestran que otros aspectos como el color del empaque, las bondades atribuidas por el boca a boca y la publicidad ayudan a tomar una decisión, y finalmente comprar este tipo de productos.

Un tipo de heurístico es el heurístico de anclaje. Éste determina rasgos de algún suceso ocurrido en el pasado que puede ayudar a realizar un juicio en el presente o en el futuro. Éste también puede ser una característica que se queda en la mente del ser humano (Naranjo, 2016). Precisamente, Naranjo toma como ejemplo las bebidas tradicionales con respecto a las mismas de tipo light, las cuales generalmente poseen un precio superior frente a las bebidas convencionales. Las personas recuerdan y relacionan los precios de 
otras bebidas que han visto para poder finalmente tomar una decisión, comparando costo - beneficio. Con esta base, se concluye que los seres humanos se enfrentan a dilemas cognitivos para comprender la complejidad en el momento de elegir. Y una forma de reducir esa complejidad es a través de los heurísticos, pues éste simplifica la toma de decisiones cuya finalidad es la satisfacción de necesidades (Naranjo, 2016).

Los Principios de la Influencia Social de Robert Cialdini (1984) son algunos ejemplos de heurísticos de uso frecuente. Estos incluyen: el compromiso, que significa que se tiende a mostrar conductas coherentes con los comportamientos previos de las personas; la prueba social, que alude a que se tiende a acomodar la opinión de uno mismo a lo que dice la mayoría para así poder encajar entre la sociedad; la escasez, que significa que las personas están más dispuestas a acercarse a algún objeto si notan que éste es difícil de conseguir; la reciprocidad, que significa que las personas tratan a los otros de la misma forma en la que los tratan; la autoridad, que dicta que uno está más predispuesto a dejarse influenciar cuando es interpelado por alguien de cargo mayor; y el último es la simpatía, que significa que uno es está más predispuesto a dejarse influir por personas con las que se tiene cierta afinidad. Además, la credibilidad también se puede utilizar como un heurístico cuando nos enfrentamos a situaciones que no son de nuestro interés o conocimiento, ya que cuando se considera que un hablante tiene una credibilidad más alta, es más probable que el oyente crea en el mensaje. La credibilidad es una forma de bajo esfuerzo y en cierto modo confiable de darnos una respuesta sobre qué decidir o creer sin tener que trabajar mucho para pensarlo (Griffin, 2012).

Tversky y Kahneman (1974) plantearon los heurísticos, en base a un experimento observando que si a un grupo de individuos se les explica la personalidad de un individuo como temeroso e introvertido, con nulo interés en su entorno, y se les pide posteriormente que valoren la probabilidad de que este hombre sea bibliotecario o comerciante; habrá mucha más probabilidad que elijan la primera opción (bibliotecario). Esto demostraría lo que es la representatividad, que viene a ser la posibilidad de que un componente pertenezca a un grupo por medio del grado de similitud que se tiene entre las características presentadas y por los prejuicios mentales que se tiene sobre estos, como se puede ver que las personas relacionan una personalidad tímida y reservada con la profesión de bibliotecario en vez de la de vendedor. Luego observaron la disponibilidad, al preguntarle a las personas si en el estado de Nueva York existen más asesinatos que 
suicidios; la mayor parte de la muestra respondió convencido que sí; sin embargo, el número de suicidios es mayor que el de asesinatos. Según Kahneman y Tversky, las personas piensan que hay más asesinatos porque estos están más "disponibles" en la memoria. Los autores concluyeron cómo es que la disponibilidad de información en la mente se ve influenciada por los medios de comunicación y esto afectaría la percepción de las personas.

Finalmente, estos autores observaron el anclaje y el ajuste conjuntamente: estos consisten en centrar una idea en un valor inicial obtenida mediante cualquier proceso, para luego ir modificándolo cuando se va añadiendo nueva información. Para demostrarlo, pidieron a un grupo de alumnos que estimaran el porcentaje de países africanos que pertenecían a las Naciones Unidas. Para ello solicitaron a cada uno que hicieran girar una rueda que señalaba un número entre 1 y 100. Seguido a ello, les preguntaron si sus apreciaciones sobre los porcentajes de países africanos que pertenecían a las Naciones Unidas eran superiores o inferiores al número que habían obtenido en la rueda. Para finalizar, les preguntaron su apreciación numérica del porcentaje. Los hallazgos señalaban que a los estudiantes a quienes les salieron números cercanos a 10 en la rueda tenían una estimación sobre los porcentajes de los países africanos entre un $10 \%$ y $25 \%$, mientras que aquellos a los que les salieron números mayores a 50, su estimación estaba entre un $45 \%$ y $55 \%$. Con ese experimento se observó que todos los estudiantes sabían que el número aleatorio inicial que obtuvieron en la rueda, no tuvo importancia para estimar la proporción de países, sin embargo, estos datos interfirieron en las aproximaciones declaradas (Kahneman \& Tversky, 1974).

\subsection{Elaboration Likelihood Model}

El modelo de probabilidad de elaboración (ELM, por sus siglas en inglés) es una teoría general del cambio de actitud, el cual tiene como objetivo organizar y comprender los procesos básicos subyacentes a la efectividad de las comunicaciones persuasivas (Petty \& Cacioppo, 1986). "El ELM sostiene que existen numerosos procesos específicos de cambio que van de bajo a alto. Cuando los procesos de operación en el extremo inferior del continuo determinan las actitudes, la persuasión sigue la ruta periférica. Por otro lado, cuando los procesos de operación en el extremo superior del continuo determinan las actitudes, la persuasión sigue la ruta central” (McNeill \& Brian 1989, p. 89). 
En la ruta central se procesa la información de forma centralizada; de esa manera las respuestas cognitivas, o las elaboraciones, son mucho más relevantes para la información. El destinatario del mensaje tiene la motivación que le sirve para procesar un mensaje y asimismo ésta se involucra con los intereses personales. Las personas evalúan en su mente la información relevante sobre los objetos en concordancia con los paradigmas mentales que tienen, llegando a una actitud razonada que se apoya en la información. El principal beneficio de la ruta central es que los cambios de actitud suelen durar mucho más (Petty \& Cacioppo, 1986).

En la ruta periférica, el destinatario del mensaje tiene una menor capacidad para procesarlo, ya que posee poco o ningún interés en el tema y no examina la información profundamente. Con la ruta periférica, es más probable que las personas se basen en impresiones generales como sensaciones, su propio estado de ánimo, señales positivas y negativas del contexto de persuasión, etc. Las personas son "perversas cognitivas" que buscan reducir el esfuerzo mental, a menudo utilizan la ruta periférica y, por lo tanto, confían en lo heurístico al procesar información (Petty \& Cacioppo, 1986).

Al respecto, Ruiz (2013) propone lo siguiente:

"La ruta periférica basa su capacidad de persuadir en cuestiones no relacionadas con el producto, como la utilización de hábitos adquiridos, colores llamativos, diseños atractivos, etc. Hacemos uso de esta ruta cuando no tenemos información completa (positiva o negativa) acerca de lo que nos ofrecen o cuando consideramos que esta información no requiere de tiempo para reflexionar; es decir, cuando pensamos “en automático"” (Ruiz, 2013, p.111).

Las personas no son conscientes de los acontecimientos importantes que suceden en sus cerebros en el preciso instante en el que un comerciante busca persuadirlos para que compren algún producto, esto ocurre porque tienen activado el modo "automático" (Ruiz, 2013).

Este modelo ha sido utilizado en diferentes investigaciones. En 1983, Petty, Cacioppo y Schumann (1983) realizaron una investigación con el fin de poder conocer los efectos que tienen las fuentes en la propaganda de un anuncio de una nueva máquina 
de afeitar desechable. Para lograrlo, segmentaron a un grupo de personas altamente identificadas con el producto muestra, señalándoles que éste sería probado primero en su área local y al final de la investigación se les daría la oportunidad de adquirir el objeto. Al mismo tiempo, juntaron a otro grupo de sujetos, los cuales debían de tener poca participación con el producto, ya que se les dijo que la máquina se comercializaría en una ciudad distante y al finalizar el experimento tendrían la posibilidad de tener una pasta dental. Agregado a ello, se modificó la fuente y el mensaje mostrado con un grupo de anuncios de individuos con deportistas populares y en los otros, sujetos con ciudadanos promedio. Además, había algunos anuncios con contenido fuerte y otros con contenido débil. Esta investigación demostró que cuando la preparación es pobre, la presencia de deportistas conocidos en el anuncio llevaría a actitudes más positivas del producto, separadamente de las características del producto presentado; mientras que cuando la confección es alta, sólo el poder del contenido manipularía las actitudes afectadas (Petty, Cacioppo \& Schumann, 1983).

Flynn, Worden, Bunn, Conolly y Dorwaldt (2011) realizaron una investigación con el fin de reducir el consumo de tabaco entre los jóvenes. Se hizo mediante el desarrollo de métodos mejorados para comunicarse con los de mayor riesgo, explorando el potencial de los mensajes de prevención de fumar en la televisión basados en el ELM. Las evaluaciones de 12 mensajes de prevención de fumar, basados en tres estrategias derivadas del ELM, se realizaron en el aula entre una muestra diversa de estudiantes de escuela intermedia de no fumadores en tres estados. Se evaluó con indicadores enfocados en las consecuencias negativas de fumar, a los estudiantes categorizados como probables de tener una mayor participación en la decisión de iniciar el consumo de cigarrillos. Se demostró que estos no mostraban ninguna reacción frente a los anuncios, y que sus ganas de fumar persistían; mientras que el grupo de estudiantes con menor rendimiento académico no entendía la información del mensaje, sin embargo, veían el cigarro dañino para su salud. Se concluyó que la razón por la cual los estudiantes que tenían un gusto por el cigarro, no tuvieron ninguna reacción. Es que su motivación por fumar era mucho más alta que su miedo por los daños del cigarrillo. Además, estos estaban acostumbrados a ver imágenes con los peligros de fumar en las mismas cajetillas, por lo que los indicadores no les generaban una reacción fuerte. Por otro lado, los estudiantes menos escépticos al no estar acostumbrados ni tener una motivación por 
fumar, cuando se les presentó los indicadores sí se asustaron, ya que automáticamente su mente relacionó al cigarrillo como dañino.

Finalmente, Boyce y Kuijer (2014) realizaron una investigación que se centró en investigar acerca de las imágenes ideales del cuerpo y de cómo los medios de comunicación predominan en la ingesta de alimentos entre las personas que restringen su dieta basados en ELM. Su hipótesis se basó en la teoría de la restricción y el ELM. Ellos hallaron que cuando manipulaban las imágenes, la atención de los participantes cambiaba. Aunque la satisfacción con el peso de las personas que comen restringido no se vio afectada significativamente por ninguna de las imágenes mostradas, la exposición a los medios publicitarios e imágenes manipuladas, no inadvertida, provocó la ingesta de alimentos de personas que se cuidaban. Esto se debió a que en ese momento las personas que se cuidaban no estaban pensando en su peso, ni en cuánto podrían engordar por ingerir los alimentos; se estaban dejando llevar por la ruta periférica, ya que los participantes se basaban en sus impresiones generales y sólo se guiaban por lo apetitoso que lucía la comida en ese momento, olvidándose por un momento de que ésta podría afectar su peso (Boyce \& Kuijer, 2014). 


\section{CAPÍTULO III: OBJETIVOS Y JUSTIFICACIÓN}

Esta investigación se realizará con el fin de analizar dos propuestas alternativas de etiquetado nutricional frente a las que se debatieron desde el 2012 en el Congreso de la República en el Perú. Con esto se busca saber si realmente estas dos alternativas, el etiquetado de Canadá y el etiquetado de estrellas de Australia, son fáciles de entender para los consumidores peruanos. Se quiere observar cómo es que la muestra elegida reacciona a las dos propuestas nunca estudiadas en el país, ya que sólo se han hecho investigaciones en base del etiquetado semáforo y octogonal, debido a que son los más conocidos y únicos propuestos en el Congreso.

En esta sección se presentarán las preguntas de investigación y los objetivos para el presente estudio.

\section{Preguntas de investigación:}

1. ¿Las personas entienden y saben acerca de los elementos nutricionales que aparecen en los empaques?

2. ¿Los consumidores tienen interés acerca de la información nutricional que aparece en los empaques?

3. ¿Las personas toman sus decisiones sobre los productos teniendo un procesamiento sistemático o un procesamiento periférico (heurísticos)?

4. ¿Los consumidores se dejan llevar por el heurístico de representatividad, atribuyendo que los productos saludables tienen un mayor precio?

5. ¿Cuál de las dos propuestas de etiquetado nutricional fue mejor comprendida por los encuestados?

6. ¿Qué etiquetado nutricional fue el más aceptado entre los encuestados?

\section{Objetivo general:}

Conocer las percepciones que tienen los usuarios sobre el efecto de dos propuestas alternativas de etiquetado, canadiense y australiano, en los consumidores peruanos como modelo alterno al ya planteado por el Congreso de la República del Perú. 


\section{Objetivos específicos:}

- Determinar el nivel de comprensión de los consumidores peruanos frente a las dos propuestas planteadas.

- Reconocer cuál de las dos propuestas de etiquetado es mejor percibida por los consumidores peruanos.

\section{Estudio previo}

En una etapa inicial de esta investigación, se realizó una encuesta a 53 personas sobre las propuestas de etiquetados planteadas. El objetivo de este estudio fue descubrir cuál de las propuestas de etiquetados canadienses tenía más relevancia para los entrevistados, debido a que Canadá tenía cuatro opciones de etiquetado y Australia sólo una. Se dividió a las personas en cinco grupos y a cada una se le asignó un etiquetado distinto para que sean evaluados.

Se descubrió que el 26\% del total de los entrevistados antes de adquirir un producto, primero ve el etiquetado nutricional, seguido por un $23 \%$ que ve el precio, lo cual afirmaba que una minoría (pues la mayoría no la lee) se detenía a leer la información nutricional. Además, se pudo ver que muchos lo hacían debido a que uno de sus familiares sufría un problema de salud como diabetes, hipertiroidismo, etc., lo que los llevaba a tomar mayor atención a los componentes dañinos que podrían tener, o simplemente querían proteger su salud y mantenerse en forma tratando de evitar los productos dañinos. Esto ayudó a conocer un poco más acerca de la percepción y motivación de las personas, para así poder formular de manera más precisa las preguntas de la nueva encuesta.

Añadido a lo anterior, se vio que la mayoría de encuestados no se percataba de la existencia de las alternativas de etiquetado canadiense y solo uno fue el que obtuvo un $100 \%$ de aprobación por parte de la muestra (Ilustración 9). Esto se dio, ya que era el más fácil de entender y diferenciar: al tener un recuadro rojo, está asociado el color a peligro o pare, por lo que genera cierta incomodidad de los consumidores al no hacerle caso. Además, tenía la frase "elevado en", lo que hizo que los consumidores tengan un sentimiento de rechazo a ese producto, dándoles a entender que si realmente lo consumen, va a ser malo para ellos. 
Gracias a los resultados anteriores, se pudo optar por elegir la alternativa de etiquetado canadiense de color rojo. De esta manera, en la investigación actual se podrá contrastar un etiquetado canadiense contra un etiquetado australiano.

\section{Ilustración 9}

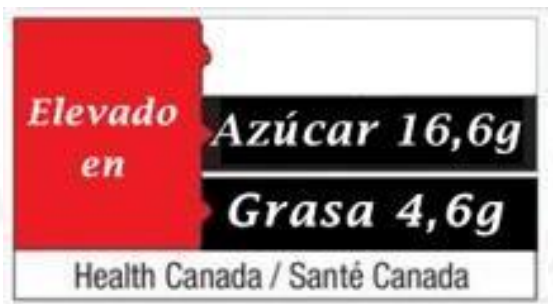

Fuente: Government of Canada 


\section{CAPÍTULO IV: METODOLOGÍA}

En este capítulo se presentará la metodología que será usada para la presente investigación y así poder dar respuesta al objetivo general y a los específicos.

\section{Enfoque, Alcance y Diseño}

El estudio tuvo un enfoque mixto, ya que se buscó comprender e interpretar las percepciones de los participantes, y de esta manera poder obtener respuestas a las preguntas de investigación planteadas.

Se tomó el enfoque cualitativo, ya que se buscó "describir, comprender e interpretar los fenómenos, a través de las percepciones y significados producidos por las experiencias de los participantes" (Hernández, 2014, p. 11). Del mismo modo se consideró el enfoque cuantitativo. Siguiendo lo que dice Hernández (2010), éste se refiere a usar la recolección de datos para probar una teoría según los objetivos y preguntas de investigación, "con base en la medición numérica y el análisis estadístico, para establecer patrones de comportamiento y probar teorías" (p. 11).

Asimismo, el diseño de esta investigación se ha basado en una metodología experimental, ya que se hizo una asignación aleatoria de los participantes para que vean una de dos opciones de etiquetado. En esta se evaluó la relación entre dos variables: el etiquetado nutricional (variable independiente), y la percepción (variable dependiente).

\section{Muestra}

Siguiendo el estudio de García (2015) se tomó como muestra a 120 personas, tanto mujeres como hombres, de edades que oscilaban entre los 30 y 40 años, y que residen actualmente en algunos de los distritos de Lima que son considerados como B y C. La importancia de los sectores B y C radica en que el $68 \%$ de la población peruana (Apeim, 2016) pertenece a estos sectores, por lo que es bastante importante conocer su perspectiva frente a este tema. Asimismo se tomó como referencia los distritos de residencia de los encuestados para así lograr saber a qué sector socioeconómico pertenecían. En la Ilustración 10 se puede observar que distritos como Surco, San Miguel, 
La Molina, Pueblo Libre, etc. están posicionados, según Apeim (2010) como distritos de sectores socioeconómicos B o medio, mientras que distritos como Los Olivos, Comas, San Martin de Porres, Rímac, etc. están considerados como sectores C o de nivel bajo. Gracias a esto será mucho más precisa la segmentación para la encuesta. Esta muestra se dividió aleatoriamente en dos grupos de similar tamaño por cada etiquetado nutricional, ya que fueron estudiados dos modelos de etiquetados.

Ilustración 10

\begin{tabular}{|c|c|c|c|c|c|}
\hline $\begin{array}{l}\text { Caracteristicas } \\
\text { predominantes }\end{array}$ & Medlo Altol Alto & Medlo & Bajo & Bajo Inferlor & Marginal \\
\hline \multicolumn{6}{|c|}{ 1.- Zona de residencia } \\
\hline Zonas distritales & Zona 7 & Zonas 6 y 7 & $\begin{array}{c}\text { Zonas } 1,2,4,5, \\
8 \text { y } 10\end{array}$ & $\begin{array}{c}\text { Zonas } 1,2,4,5 \\
\text { y } 9\end{array}$ & Zonas $1,3,5$ y 9 \\
\hline Distritos & $\begin{array}{c}\text { San Isidro, San Borja, } \\
\text { Santiago de Surco, La } \\
\text { Molina y Miraflores. }\end{array}$ & $\begin{array}{c}\text { Surco, San } \\
\text { Miguel, Pueblo } \\
\text { Libre, Jesús } \\
\text { Maria, Los Olivos, } \\
\text { Lince, La Molina. }\end{array}$ & $\begin{array}{c}\text { Comas, Los } \\
\text { Olivos, S M P. } \\
\text { Cercado, Rimac, } \\
\text { Breña, La Victoria, } \\
\text { San Luis, Callao. } \\
\text { S J M. }\end{array}$ & $\begin{array}{c}\text { S. J. L } \\
\text { Comas, S.M.P. } \\
\text { Cercado, Rimac, } \\
\text { Ate, El Agustino, } \\
\text { S. Anita, S. J. M. } \\
\text { V.E.S v V. M .T }\end{array}$ & $\begin{array}{l}\text { Ventanilla, Puente } \\
\text { Piedra, S. J. L... } \\
\text { V. E. S., V. M.T. } \\
\text { Ate y Chaclacayo }\end{array}$ \\
\hline
\end{tabular}

Fuente: Apeim (2016)

\section{Procedimiento}

Para el reclutamiento de participantes se realizaron tres preguntas filtro: ¿En qué distrito usted reside actualmente? ¿Usted es quien suele realizar las compras del hogar?, ¿Suele comprar en supermercados?; de esta manera se identificó si es que esta persona es la que tiene la decisión de compra en la casa. Asimismo, se pudo ver si es que va a supermercados en donde tiene la ventaja de poder comparar productos y etiquetados nutricionales. Si es que respondía "sí" a las dos preguntas, se les aplicaba la encuesta; de no ser así, no se les aplicaba la encuesta.

Se utilizó la página web https://www.randomizer.org/ para poder asignarle un tipo de etiquetado nutricional a los encuestados, ya que al ser una investigación experimental, la selección de qué participante ve qué etiquetado nutricional debía de ser al azar. Gracias a esta página, las personas tenían $50 \%$ de posibilidades de que les tocara cualquiera de las dos opciones.

El procedimiento que se llevó con las personas que ingresaban en la encuesta, se dio de la siguiente manera: 
- Paso 1: Se les explicaba en qué consistía la investigación.

- Paso 2: Se realizaban las 3 preguntas filtro.

- Paso 3: Los encuestados que respondían correctamente las 3 preguntas filtro, leían y firmaban el consentimiento informado.

- Paso 4: Se les entregaba el cuestionario.

- Paso 5: Respondían las preguntas 1 hasta la 15.

- Paso 6: Se aleatorizaba. Se usaba la página https://www.randomizer.org/ desdeel celular, para poder asignar un etiquetado nutricional al encuestado.

- Paso 7: Se les entregaba la caja de cereal Chocapic con el respectivo etiquetado nutricional.

- Paso 8: Se observaba si los encuestados fijaban su mirada en el etiquetado nutricional.

- Paso 9: Los encuestados evaluaban la caja de cereal y respondían las preguntas 16 y 17.

- Paso 10: Se les pedía a los encuestados que fijen su atención en el etiquetado nutricional para poder responder las preguntas restantes.

- Paso 11: Se terminaba la encuesta y se agradecía a los participantes.

\section{Unidad de análisis}

Como la unidad de análisis, tuvimos a la persona idónea.

\section{Herramientas de investigación}

Se elaboró un cuestionario con preguntas tanto cerradas como abiertas (ver Anexo 3). Para poder realizar esto, se utilizó un producto muestra, que en este caso son dos cajas del cereal Chocapic. (Ilustración 11 y 12)

\section{Ilustración 11}




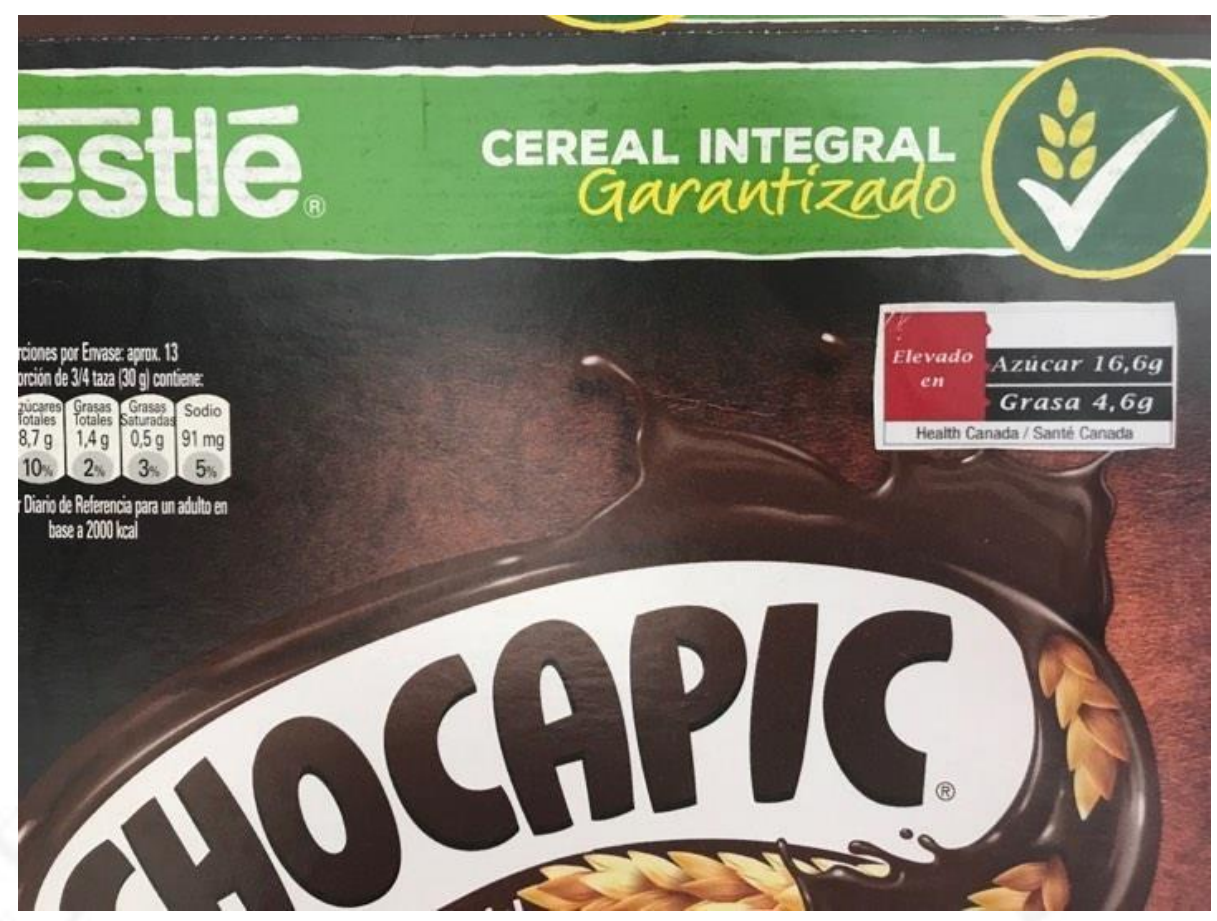

\section{Ilustración 12}

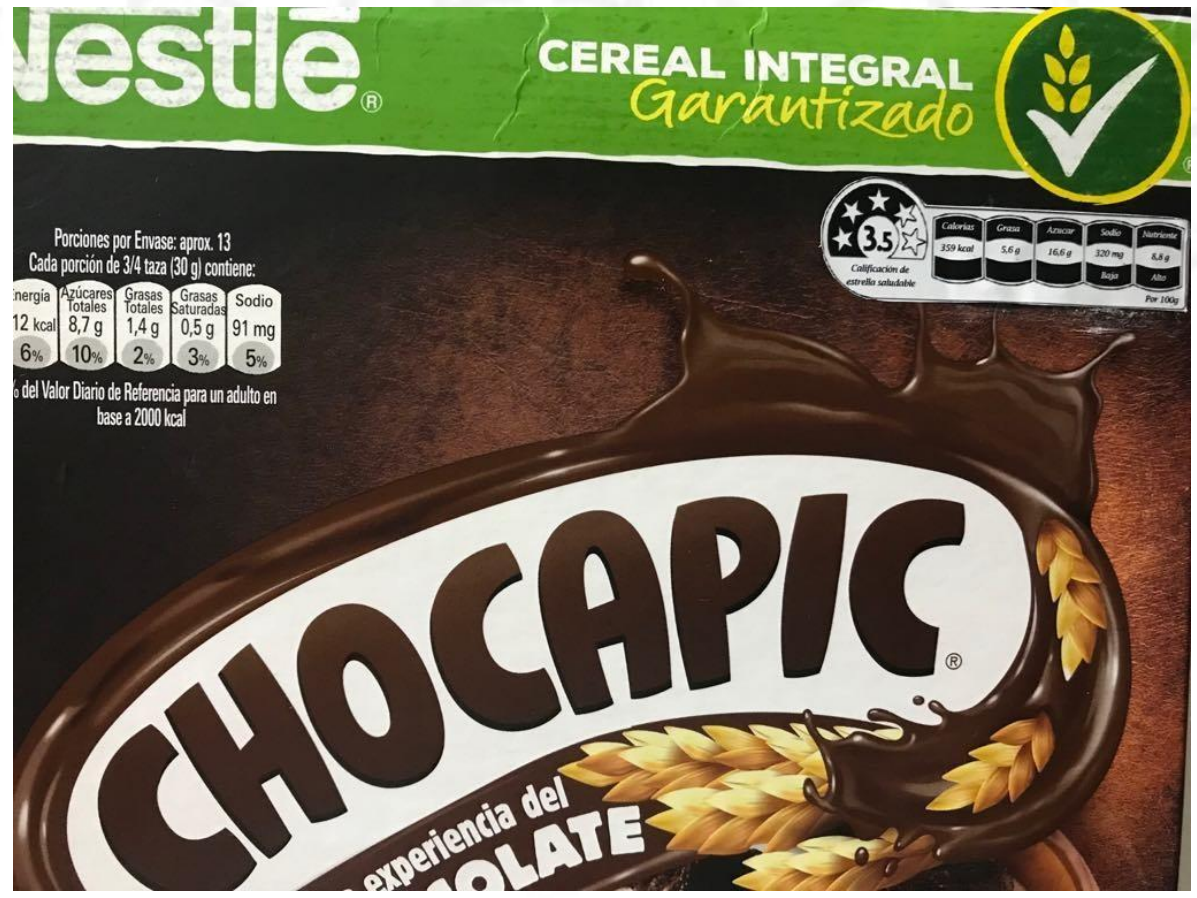

Se imprimieron las etiquetas alternativas en un tamaño de $4 \times 3 \mathrm{~cm}$ y se pegaron en la parte superior frontal del producto para que así, al momento de realizar el cuestionario, las personas pudieran entender el etiquetado de una manera más rápida, didáctica y sencilla. Además, se pudo observar si es que realmente entendían o se percataban de la existencia del etiquetado, o si no lo notaban y era totalmente desapercibido. 
Para poder tabular las respuestas, se usó Microsoft Excel. Con este se pudo crear la matriz de datos de las encuestas, lo que facilitó el análisis de los datos. Estas pruebas incluyeron la generación de gráficos y tablas comparativas.

\section{Ética de la investigación}

Para la obtención de datos en el trabajo de campo, se utilizó un documento para el consentimiento informado (ver Anexo 2), donde se confirmó que los actores participantes de las encuestas estaban enterados sobre los fines, implicancias del estudio y la contribución que daría su aporte. El primer párrafo sirvió para certificar que existiera aprobación con el uso de la información. Se le informo a los encuestados que su participación era premeditada y que la información solo se usaría para fines académicos. 


\section{CAPÍTULO V: RESULTADOS}

De acuerdo al marco de la metodología señalada, se realizó la encuesta a una muestra total de 120 personas, desde el día 09 de abril al 15 de mayo del 2019. Durante el reclutamiento se preguntó a 172 personas si accedían a realizar la Encuesta; de éstas: 32 dijeron que no tenían tiempo para hacerla, 18 no respondieron correctamente las tres preguntas filtro por lo que no pudieron ser encuestadas, y otras 2 abandonaron el cuestionario. Es por ello, que finalmente la muestra es de 120 personas.

Las edades de los participantes oscilaron entre los 30 y 50 años. El $70.83 \%$ se encontraba entre los 30 y 39 años, en tanto el otro $29.17 \%$ oscilaba entre los 40 y 50 años. Agregado a ello, el 33\% tenía 0 hijos, 23\% un hijo, 28\% dos hijos y el otro 16\% igual o más de tres hijos. Por otra parte, el $53 \%$ de los encuestados fueron hombres, el $45 \%$ mujeres y otro $2 \%$ marcó la opción “otro”. Las ocupaciones que más se repitieron fueron asistente, abogado, empleado y secretaria.

Los distritos de procedencia se dividieron de la siguiente manera: $12.5 \%$ Surco, 10.8\% Breña, 9.16\% Callao, 9.16\% S.J.M., 9.16\% San Miguel, 9.16\% La Molina, 7.5\% Cercado, 6.66\% SMP, 5\% Chorrillos, 4.16\% Rímac, 3.33\% Los Olivos, 3.33\% Pueblo Libre, 3.33\% La Victoria, 2.5\% Lince, Comas 2.5\%, y 1.66\% San Luis.

\section{Nivel de comprensión de los encuestados}

En base a los objetivos y preguntas planteadas en la investigación, se pudo hallar y contrastar distintos tipos de información. El primer objetivo fue determinar el nivel de comprensión de los consumidores frente a las dos propuestas planteadas; éste tuvo 4 preguntas de investigación.

La primera pregunta fue para conocer si las personas entienden y saben acerca de los elementos nutricionales que aparecen en los empaques. En los resultados se obtuvo que el $63.33 \%$ de los encuestados están de acuerdo o totalmente de acuerdo en que entienden los términos de la tabla nutricional tales como sodio, azúcar, grasas, entre otras; mientras que el $11.66 \%$ no está de acuerdo y el $25 \%$ restante no se encuentra ni de acuerdo ni en desacuerdo (Ilustración 13). Además de eso, el 59.16\% no conoce los límites 
máximos para la salud acerca del sodio, azúcar y grasa en los productos; de este porcentaje el $22.53 \%$ es por falta de interés y el $76.05 \%$ por falta de información.

Con esta primera información se puede concluir que la mayoría de personas sí conocen acerca de los elementos nutricionales, sin embargo, no tienen la suficiente información como para complementar sus conocimientos básicos y lograr una correcta alimentación.

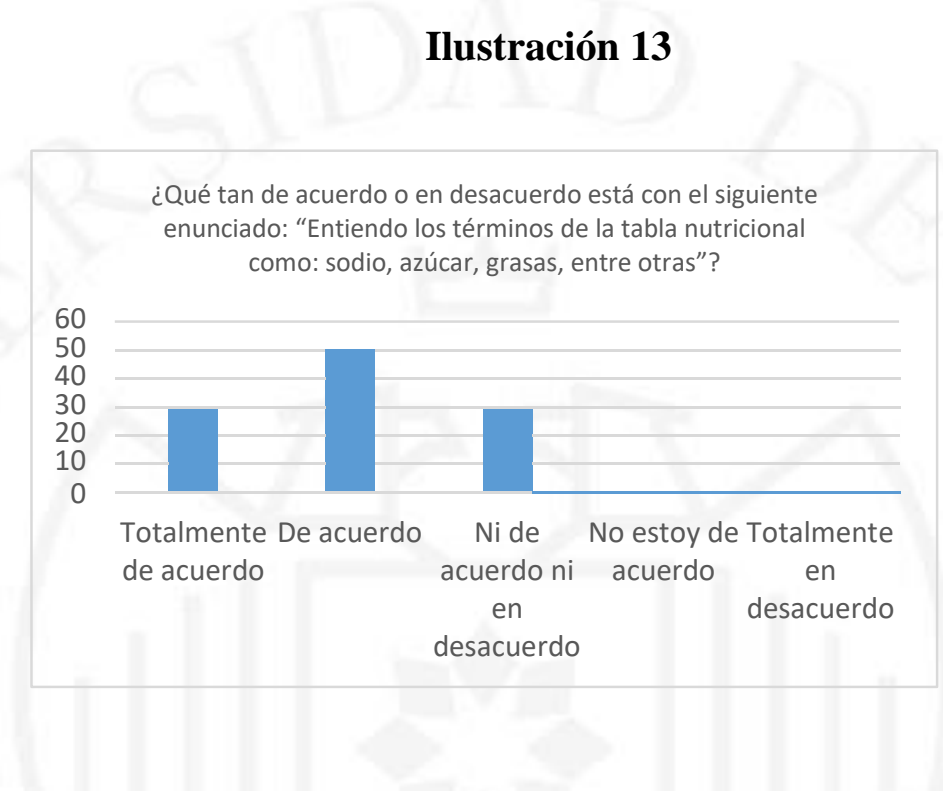

La segunda pregunta tuvo como objetivo indagar si es que los consumidores tienen interés acerca de la información nutricional que aparece en los empaques. Aquí se encontró que el $75.63 \%$ considera que son personas que se preocupan por tener una alimentación saludable, tanto para ellos como para su familia; de este porcentaje el $36.66 \%$ respondió que para adquirir un producto suelen observar primero el reconocimiento del producto en el mercado, un $33.33 \%$ mira primero el etiquetado nutricional, $21.11 \%$ prioriza que el producto tenga etiquetados con la palabra "light" o "bajo en calorías", mientras que un 5.55\% marcó "otro" en donde uno indicó que no consume alimentos procesados, otras dos personas comentaron que observan la cantidad de azúcar y una reportó que suele adquirir los productos que compraba su mamá, y el otro $2.22 \%$ prioriza un empaque atractivo. Por otro lado, el $65 \%$ de encuestados sí está de acuerdo en que observan siempre el etiquetado nutricional antes de adquirir un nuevo producto, $25 \%$ no está de acuerdo ni en desacuerdo, y el $11.16 \%$ no está de acuerdo. 
En conclusión, se encontró que los consumidores sí tienen interés acerca de la información nutricional, ya que más de la mitad se preocupa por tener una alimentación saludable, observando la información nutricional u observando las etiquetas "light", antes de consumir algún producto.

En tercer lugar, se preguntó si las personas toman sus decisiones sobre los productos, mediante un procesamiento sistemático o un procesamiento periférico (heurísticos). El análisis nos dio como resultado que el $41 \%$ de encuestados cuando va al supermercado y debe elegir entre un producto $u$ otro, lo que hace que finalmente se decida por una opción (Ilustración 14) es el precio, seguido por otro $37.60 \%$ que ve la información nutricional, un $17.94 \%$ ve la marca y por último $2.56 \%$ marcó "otro", tal como los productos que usaba su mamá. Además, el 58.33\% respondió que sí toma en cuenta las referencias que le dan sus conocidos. Por otro lado, el 56.66\% no tiene una lista de productos con las marcas específicas que desea comprar. El 35\% respondió que comen todo tipo de comidas, el $51 \%$ consume comida hecha en casa y el $10.83 \%$ cuida su alimentación y dieta. Agregado a ello, el $89.16 \%$ comentó que sería algo probable que eliminen todos los productos procesados de su alimentación y el otro $10 \%$ dijo que sería poco probable. El $93.33 \%$ aseveró que no comprarían un producto que es dañino para la salud: la razón para esto es que un $38.43 \%$ no quiere dañar su salud, seguido de un $21 \%$ que comentó que sería absurdo consumir un producto que hace daño.

Se puede concluir, que las personas basan sus decisiones teniendo un procesamiento sistemático, ya que analizan y comparan los precios y la información nutricional, cuando quieren adquirir un producto. Sin embargo, la mayoría al no tener una lista determinada de productos, se podrían dejar influenciar por sus conocidos, generando así un procesamiento periférico. 


\section{Ilustración 14}

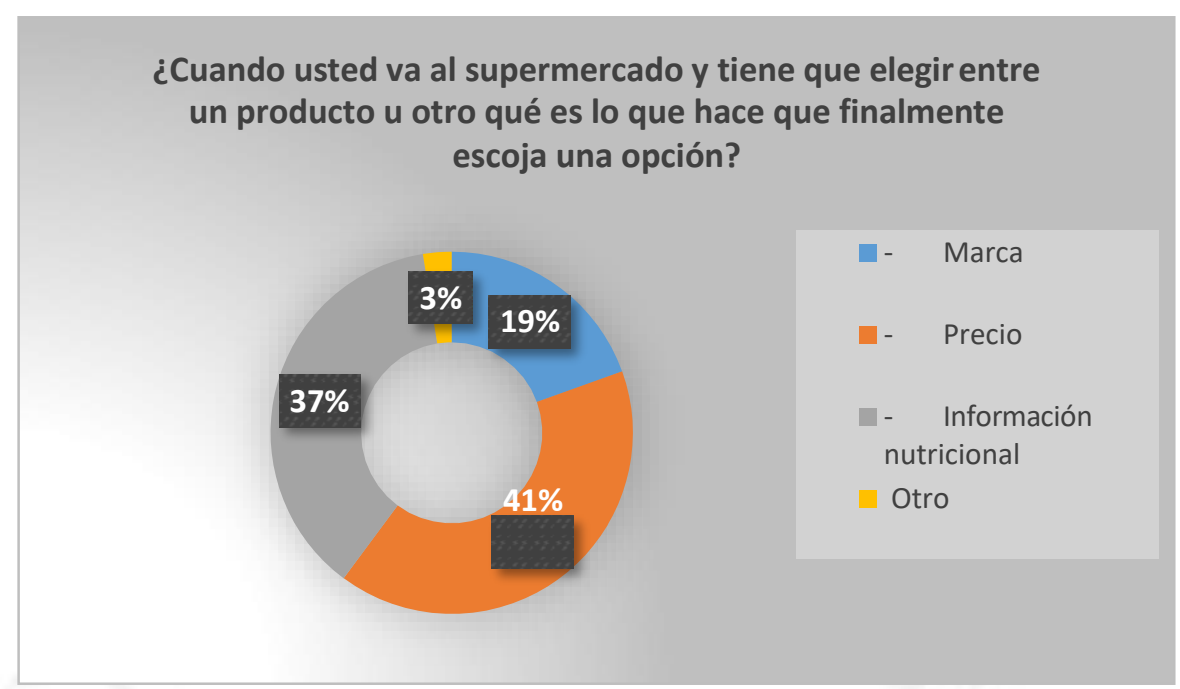

Por último, se indagó si los consumidores se dejan llevar por el heurístico de representatividad, atribuyendo que los productos saludables tienen un mayor precio. Al preguntarles a los encuestados si es que consideran que los productos saludables tienen un mayor precio en comparación a los demás productos del mercado, el 55.83\% respondió que sí, siendo la razón de ello que un $29 \%$ considera que alimentarse saludablemente es caro, o que los productos sanos son escasos o porque para producirlos se necesitan mayores insumos; un 32\% dijo que las personas están acostumbradas a productos dañinos y por eso los saludables son más costosos. El 56.66\% considera que el precio no sería uno de los motivos por el que compraría o dejaría de comprar un producto marcado como saludable, ya que el $32 \%$ opina que si es bueno para la salud, no importaría el costo. Los que marcaron que el precio sí sería uno de los motivos por el que no comprarían productos saludables es porque las compras dependen de su poder monetario. Agregado a esto, el $62.5 \%$ considera que los productos saludables están sobrevalorados.

En conclusión, se encontró que la mayoría de personas se dejan llevar por el heurístico de representatividad en el sentido que atribuyen que los productos saludables son caros, sin embargo, éste no afectaría a la mayoría en su decisión de compra, ya que consideran que la salud prima sobre el precio, por lo que a la hora de adquirir un producto, sí se guiarían por el procesamiento sistemático.

\section{Etiquetado mejor percibido por los encuestados}


El segundo objetivo de la investigación fue reconocer cuál de las dos propuestas de etiquetado es mejor percibida por los consumidores. Para conseguir las respuestas de éste, se dividió la muestra en dos grupos: uno vio el etiquetado de Canadá y el otro, el de Australia. Se les asignó el etiquetado aleatoriamente gracias a una página web. Esto nos dio como resultado que a 61 personas se les asigne la propuesta australiana y a las otras 59 , la propuesta canadiense.

Aquí se tuvo dos preguntas de investigación. La primera fue determinar cuál de las dos propuestas de etiquetado nutricional fue mejor comprendida por los encuestados. Se les mostró un empaque de cereal Chocapic. Al verlo, se les preguntó si es que lo consideraban un producto saludable (Ilustración 15 y 16). Como resultado, se observó que el $16.39 \%$ de las personas que vieron el etiquetado de estrellas basó su respuesta en la información nutricional, $14.75 \%$ en las imágenes y el $11.44 \%$ en el precio del producto, mientras que los que vieron el etiquetado canadiense el $28 \%$ basó su respuesta en la calidad del producto, un 25\% marcó "otro": de ese porcentaje 14\% se dejó guiar de la información nutricional, un $20 \%$ de la marca, y un $6 \%$ observó el etiquetado canadiense. Asimismo, el 68\% de los encuestados, al ver el etiquetado australiano, comentaron que estaban de acuerdo en que éste hacía que comprender la tabla de información nutricional sea mucho más sencillo y rápido; el 15\% no estaba de acuerdo y el 14.75\% ni de acuerdo ni en desacuerdo; mientras que en el etiquetado de Canadá, el 78\% estuvo de acuerdo o completamente de acuerdo. Al preguntarles si consideraban que el etiquetado australiano es sencillo de entender, $57.37 \%$ respondieron que sí, ya que especifica cantidades y es claro. Por otro lado, el 36.06\% marcó “no”, debido a que según ellos éste es confuso para las personas que no comprenden porcentajes ni tienen conocimientos nutricionales, ya que en sí no explica nada. En la propuesta canadiense el $66.10 \%$ dijo que sí era sencillo de entender, ya que estaba claramente resumido y tenía letras grandes, además que el color rojo lo hacía interesante; mientras que el 33\% que marcó "no" dijo que no todas las personas entienden los términos nutricionales. Los encuestados comentaron que el cambio que le harían a ambos etiquetados sería aumentarles su tamaño.

Gracias a lo anterior, se puede concluir que la diferencia entre los porcentajes de ambos etiquetados es mínima, pues los dos han sido de sencilla comprensión para los consumidores; sin embargo, un punto importante para destacar es que un 6\% de la muestra a la que se le asignó el etiquetado de Canadá, para responder la pregunta de si es que consideraban el producto "Chocapic"como saludable, observaron dicho etiquetado y 
respondieron la pregunta según su percepción respecto al etiquetado canadiense. Eso no pasó en el caso del etiquetado australiano, ya que nadie lo mencionó para responder la misma pregunta.

\section{Ilustración 15}

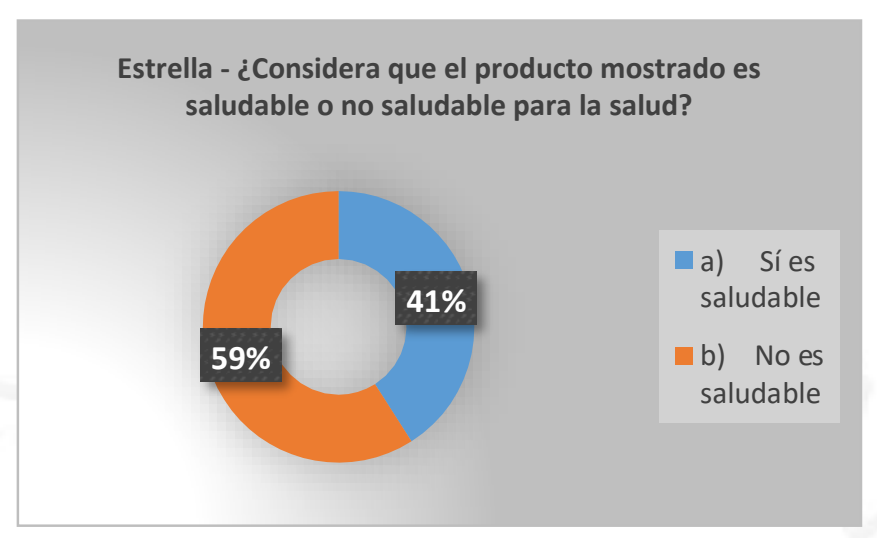

\section{Ilustración 16}

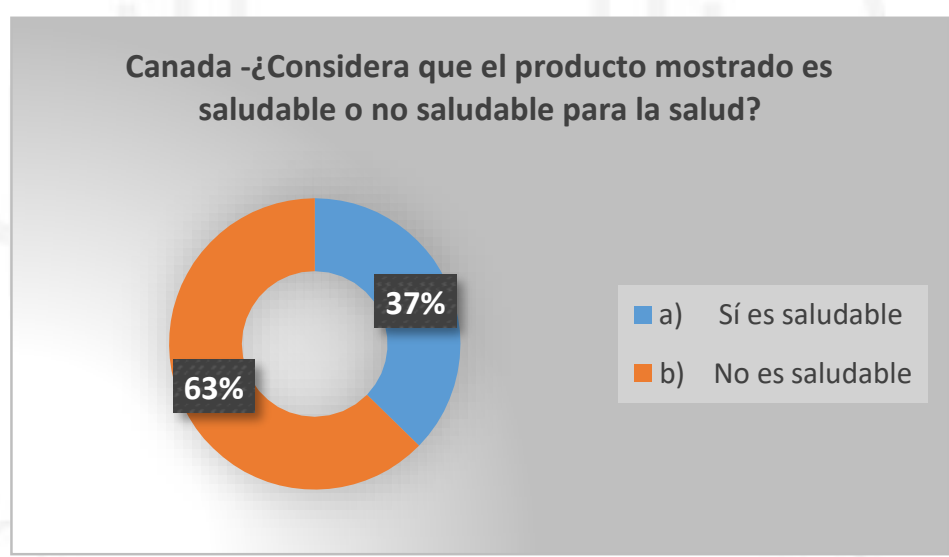

La segunda pregunta de investigación para este objetivo fue qué etiquetado nutricional es el más aceptado entre los encuestados. Al mostrarles el cereal Chocapic, el $29.50 \%$ de la muestra al que se le asignó la opción de estrella, (Ilustración 17 y 18) fijó su primera mirada hacia el etiquetado asignado, mientras que en la opción canadiense el $32.20 \%$ fijó su vista en el etiquetado mencionado. Agregado a ello, al preguntarles si consideraban que el producto era saludable, el $40.98 \%$ de los encuestados que vieron la propuesta australiana dijeron que sí lo consideraban sano, mientras que en el etiquetado canadiense el $37.12 \%$ afirmó que era saludable. Al preguntarles si existiera ese tipo de 
etiquetado en sus productos, ellos empezarían a tomar más atención a los ingredientes dañinos que podrían tener sus comidas, el $71 \%$ dijo que estaba de acuerdo y el $10 \%$ que no estaba de acuerdo, mientras que en la propuesta canadiense el $80 \%$ comentaron que estaban de acuerdo. El 68\% de los encuestados que les tocó la propuesta de Australia, afirmaron que al observar esa opción de etiquetado en sus productos indicando que estos poseen porcentajes altos de azúcar, grasa o sodio, dejarían de comprarlo gracias al etiquetado, mientras que en el canadiense el $82 \%$ estaba de acuerdo con este enunciado. Luego de analizar las respuestas a la pregunta abierta sobre las ventajas del etiquetado canadiense, un 36\% mencionó que una gran ventaja del etiquetado canadiense es que al ser tan sencillo puede ayudar a las personas a alimentarse mejor, otro $19 \%$ dijo que éste ayudaría a reducir la obesidad infantil y otro $19 \%$ que este etiquetado muestra de forma más simple el valor nutricional que los etiquetados convencionales; además de ello un $13 \%$ añadió que es vistoso gracias a su color. En el etiquetado australiano el $44 \%$ dijo que éste genera conciencia sobre la alimentación saludable, un $20 \%$ que los padres sean más cuidadosos con sus hijos, $18 \%$ que las personas tomen mayor atención a la información nutricional gracias a su simplicidad, y un 19\% ninguna.

\section{Ilustración 17}

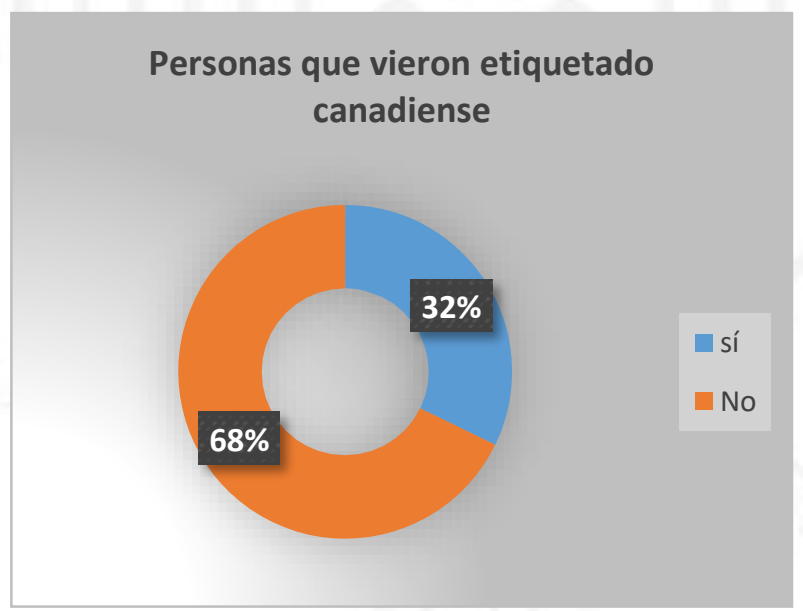




\section{Ilustración 18}

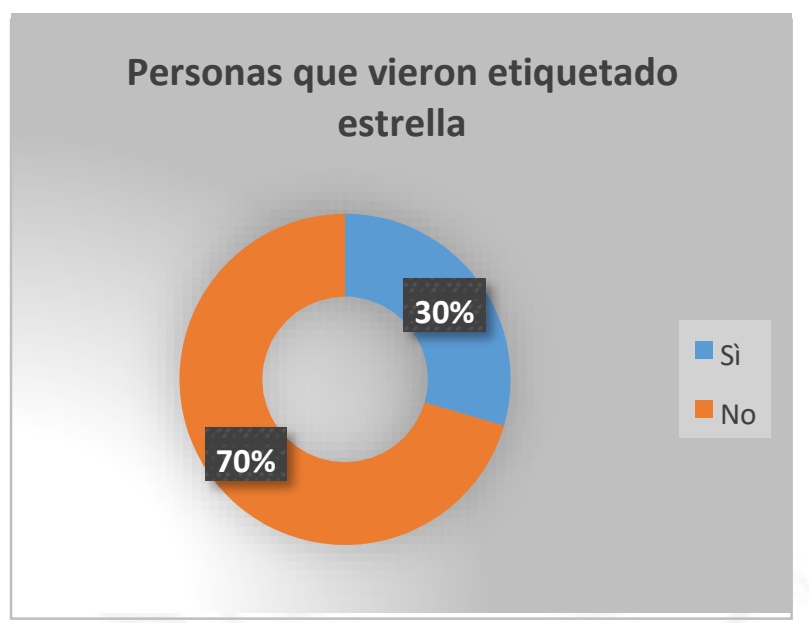

Luego de analizar las respuestas a la pregunta abierta sobre las desventajas del etiquetado canadiense, un 36\% mencionó que no encontraba ninguna, 32\% dijo que las empresas venderían menos, $11 \%$ mencionó que debería decir cantidad de calorías, y otro $7 \%$ que no explica nada, ya que es muy pequeño. En el canadiense un $40 \%$ dijo que no tenía ninguna desventaja, un 35\% que las empresas venderían menos y el resto comentó que las personas podrían ignorarlo, ya que se necesita conocimiento nutricional para comprenderlo. Acorde a lo anterior, se puede concluir que el etiquetado canadiense es el más aceptado entre los consumidores, a pesar de que las cifras entre ambos no son tan alejadas; al etiquetado canadiense le encuentran mayores ventajas, ya que es más sencillo de entender y ver gracias a su color rojo. Agregado a esto, lo interesante de resaltar es que muchos encontraron como una desventaja en ambas opciones de etiquetados que las empresas reducirían sus ventas si ellos existieran.

\section{Diferencias entre grupos de la muestra}

Según literatura mencionada en los capítulos anteriores, existen algunas diferencias en ciertos grupos de la investigación; por lo tanto, se exploraron y analizaron los datos por tenencia de hijos, género y edad. Sólo se hallaron relevantes en diferencias por edad y género.

Según, Mercado Negro (2018), en los familias peruanas las madres cada día le toman mayor importancia a la alimentación sana, natural y balanceada de sus familias, excluyendo los preservantes y exceso de grasa. Sin embargo, en la investigación no se encontraron grandes diferencias entre las personas con hijos y las que no los tienen. 
Un estudio publicado por Datum (2018) encontró que la gran mayoría de peruanos no hace dieta (87\%). Ésta la realizan principalmente las mujeres; la mitad de ellas, cuando la hacen, deciden por ellas mismas lo que consumirán, mientras que para los demás, es un experto quien les dice qué régimen que deben seguir. Asimismo, un estudio realizado por Deloitte (2010) detectó que las mujeres muestran más preocupación de forma general en su alimentación, mostrando un $82 \%$ más de interés por la información nutricional que los hombres, ya que buscan prevenir enfermedades cardiovasculares y mejorar estéticamente la zona abdominal.

Por otro lado, el doctor David Frederick, en la Universidad de Chapman (2016), descubrió que a los hombres cada vez les preocupa más su aspecto, pero la presión en ellos sigue siendo diferente. Esto se da, ya que el aspecto físico ocupa un lugar vital en la escala de aspectos que las personas consideran fundamentales para ser felices: ocupando el tercer lugar en el caso de las mujeres, y el segundo en el caso de los hombres.

Los estudios anteriores concuerdan con la presente investigación, debido a que se reveló que un $86 \%$ de las mujeres encuestadas afirman preocuparse por su alimentación y la de su familia, y un $50 \%$ observa la información nutricional antes de adquirir un producto, mientras que un $70 \%$ de hombres afirmó preocuparse por su alimentación y sólo un $28 \%$ ve la información nutricional.

Finalmente, según la revista Quality Assurance and Food Safety (2018), los millennials son los que traen un nuevo significado acerca de la alimentación sana priorizando lo simple, en la preparación y en el producto final, esto genera una tendencia a alimentos más frescos. Asimismo, en un estudio realizado por Nielsen Global Health (2014), se puede ver que los millennials están más preocupados por su nutrición que la generación X (ver Ilustración 19).

\section{Ilustración 19}




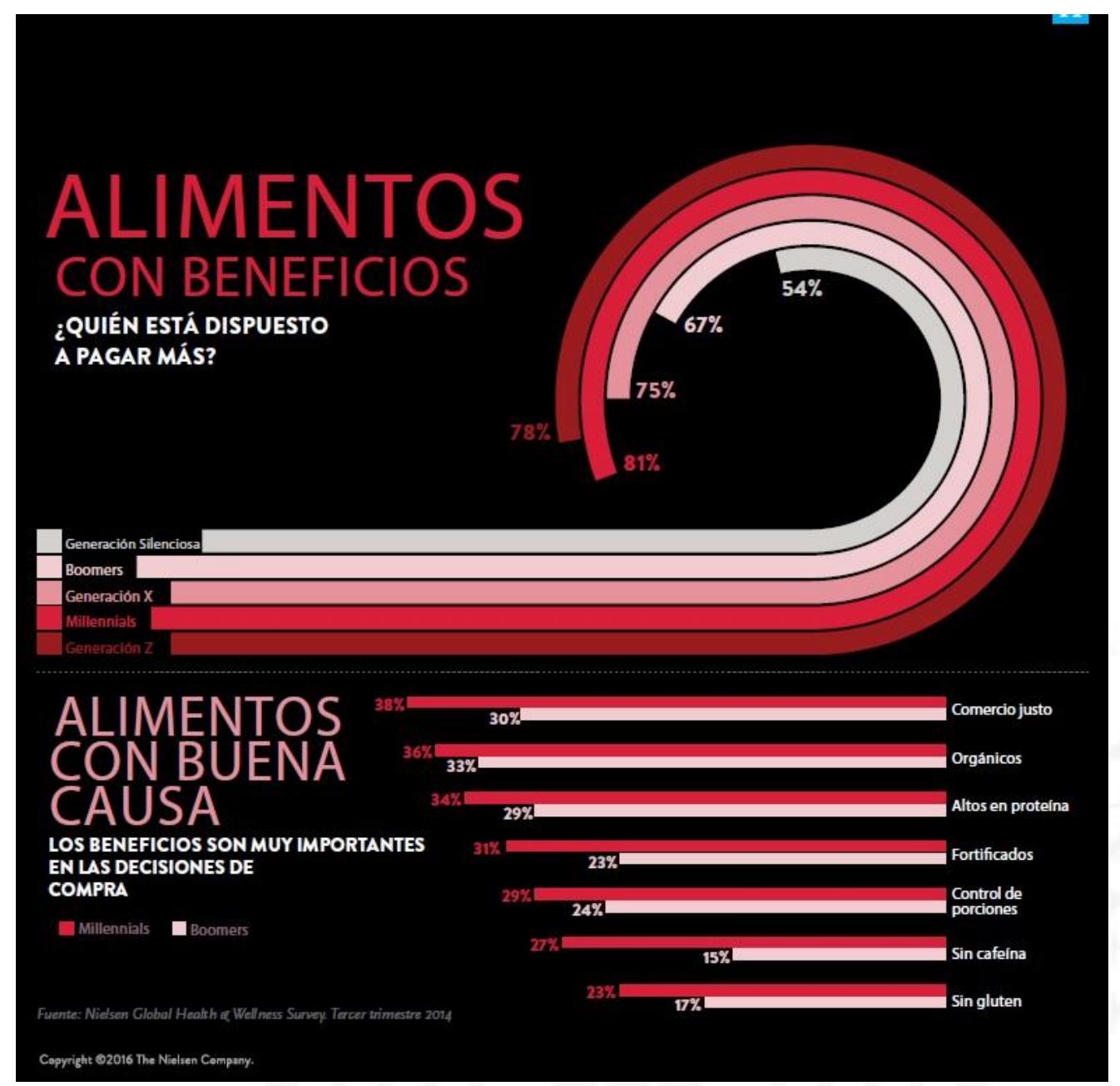

Fuente: Nielsen Global Health (2014)

En la presente investigación se pudo ver que un 44\% de los millennials (26 a 39 años) conoce acerca de los límites máximos para la salud de los elementos nutricionales, versus un 31\% de la generación X (39 A 50 años). Finalmente, los demás resultados respecto a decisiones de compra basados en la información nutricional dieron respuestas similares por parte de ambos grupos. 


\section{CAPÍTULO VI: DISCUSIÓN}

El objetivo general que se planteó en esta investigación fue conocer las percepciones que tienen los usuarios sobre dos propuestas alternativas de etiquetado, canadiense y australiano, en los consumidores como modelo alterno al ya planteado por el Congreso de la República del Perú. Gracias a la encuesta realizada a un total de 120 personas, se pudo descubrir que la mayor parte de la encuestados están interesados por llevar una alimentación saludable, ya que más de la mitad de ellos están al tanto de los elementos nutricionales, lo cual es bastante importante, debido a que en el Perú han crecido las cifras de obesidad según la INEI (2018b). Asimismo, fue mucho más sencillo para las personas realizar la encuesta teniendo cierto conocimiento previo referente a los términos nutricionales presentados en las preguntas.

Actualmente existe un grave problema: las personas están interesadas en la nutrición, sin embargo, no tienen información cercana a ellas sobre ésta. Eso se pudo constatar con los resultados, debido a que un $76 \%$ de la muestra no conoce los límites de los elementos nutricionales a causa de falta de información. Todo esto puede generar un sesgo en los consumidores, por lo que podrían comprar productos por falta de información, que según ellos son saludables, pero no lo son. Es importante destacar que según el modelo económico racional, las personas se dejan llevar por sus intuiciones y lo visual, lo cual se demostró en las encuestas, ya que muchos al ver los términos "light" lo atribuían a saludable; sin embargo, esto no siempre es cierto, debido a que para que a un producto se le ponga la etiqueta de "light", el fabricante debe haber reducido en un $30 \%$ su aporte calórico (Nutrition Bulletin, 2012). Esto no transforma a un producto en sano, simplemente lo reduce en un elemento nutricional, creando un sesgo en las personas sin saber qué realmente es un producto sano.

Acorde con lo anterior, el primer objetivo específico fue determinar el nivel de comprensión de los consumidores frente a las dos propuestas planteadas. Se pudo descubrir en el estudio, que los clientes, para comprar un producto, primero analizan sus decisiones y no se dejan llevar por heurísticos, ya que la mayoría priorizaba la compra de sus productos por la información nutricional o el precio. Asimismo, esto ayudó a que las 
personas pudieran comprender mejor las opciones planteadas, ya que tenían un conocimiento previo y un interés por ello. Sin embargo, un grave problema es que la mayoría de los encuestados no tienen una lista fija de productos, y a la vez toman en cuenta la referencia de sus conocidos cuando deben decidir sus compras. Esto podría generar que, a pesar de que tengan conocimientos de nutrición y comprendan los elementos nutricionales, tomen malas de decisiones en sus productos, debido a que se dejarían llevar por el procesamiento periférico, por el cual simplemente se basan en características que ya han escuchado o información inmediata, sin analizar previamente cuánto daño podría hacerle un producto e ignorando los etiquetados.

Se debe cambiar la percepción a las personas de que los productos saludables son costosos, ya que no todos los productos son caros, tales como: frutas, verduras, legumbres, entre otros recomendados por los profesionales de la salud (FAO, 2016). El $44 \%$ de los encuestados comentó que el precio sería un factor determinante cuando desean comprar productos saludables, lo cual es malo, ya que el heurístico de representatividad afecta su decisión de alimentarse saludablemente. Es por ello que el Estado debería informar mejor a las personas sobre qué productos son saludables, para que de esta forma no todos tengan la idea de que, si quieren comer sano, tienen que invertir mucho.

El segundo objetivo específico fue reconocer cuál de las dos propuestas de etiquetado es mejor percibida por los consumidores. En este caso no hubo gran diferencia en los porcentajes entre ambos etiquetados. Lo interesante de destacar es que entre un $29 \%$ y $32 \%$ de los encuestados fijaron su primera mirada en la etiqueta. A pesar de ello, algunas de esas personas respondieron que el cereal Chocapic es saludable, a pesar de que en las etiquetas de ambos dice que no lo es. Al preguntárseles si es que consideraban que las propuestas eran sencillas de entender, la razón que dieron las que respondieron negativamente fue que los términos son complicados de entender. Esto iría conectado con las primeras preguntas del cuestionario, ya que la mayoría decía que la razón por la que no conocían perfectamente los valores nutricionales era por falta de información y no de interés. 
Igualmente se pudo determinar que el etiquetado canadiense fue mejor percibido por los encuestados; sin embargo, un problema que existe en ambos es que las personas consideran que ambos etiquetados tienen un tamaño muy pequeño. El tamaño en el que les fue presentado es el tamaño indicado de Canadá y de Australia, por lo que no podría haber sido impreso más grande. Sin embargo, la función de estos etiquetados es ser notorios para poder generar un cambio en los consumidores, y si su tamaño afecta su objetivo éste debería ser modificado.

Según los estudios que se han realizado en otros países mencionados anteriormente, las personas se dejan influenciar o desean comprar productos que los atraigan visualmente. El cereal Chocapic mostrado "no tenía representado al perro" (Ilustración 20), lo cual generó que en algunas ocasiones los encuestados preguntaran si éste era el mismo cereal que el Chocapic con el perro, ya que no estaban acostumbrados a verlo sin él. Por otro lado, $15 \%$ de los encuestados pensaron que el cereal era saludable por las imágenes presentadas en él, tales como: figuras de trigo, etiquetas de "cereal integral", "más fibra" y el color verde. Estas generaron confusión e hicieron creer que el cereal era saludable, ya que siguieron la ruta periférica en donde simplemente se guiaron por lo visual, sin razonar ni reflexionar sobre el producto.

\section{Ilustración 20}

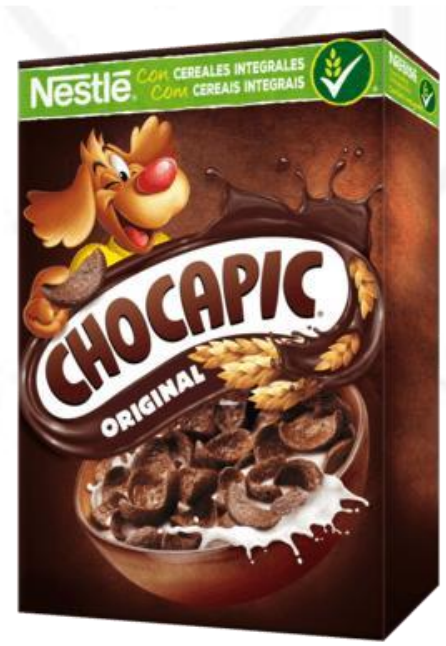

Nestlé (2016) 
En Chile, hicieron una campaña masiva para que la gente se informara en todos los aspectos sobre los íconos y elementos nutricionales, tal como es explicado anteriormente; es por ello que estas etiquetas sí han funcionado (Organización de las Naciones Unidas para la Alimentación y la Agricultura y Organización Panamericana de la Salud, 2017).

En el Perú se puede constatar que hay interés, pero no información; por lo tanto, es bueno que las personas lean la información nutricional antes de adquirir un producto. Sin embargo, se necesita que se haga mayor publicidad, ya que la obesidad es un grave problema en nuestro país: $2 \%$ de los encuestados opinaron que una desventaja del etiquetado es que no hay publicidad respecto a estos.

En los países en donde se han instaurado estos etiquetados las empresas han tenido que cambiar y modificar los ingredientes de los productos, porque el Estado los regula. Asimismo, según los estudios que se han hecho en estos países, las ventas de productos con etiquetas de alto en sodio, azúcar o grasa, han disminuido considerablemente (Food Standards, 2013). Sin embargo, una desventaja que encontraron muchos de los encuestados es que si se instauraran estos etiquetados las empresas bajarían sus ventas, lo cual en realidad sería lo ideal, pero la muestra de este estudio lo ve como una desventaja.

Tal como se ha mencionado en capítulos anteriores, las tendencias de alimentación han cambiado en los consumidores, ya que como se ha demostrado en este estudio, muchas de las personas se interesan por saber qué es lo que están consumiendo. Esto es bastante importante, ya que las personas le toman mayor importancia a su salud, solo que muchas veces los empaques atractivos pueden confundirlos, tal como lo explica Alvares (2011), y al no tener información concreta caen en la desinformación.

Luna y Morán (2016) afirman que la mayoría de personas no entienden la información que se les brinda en los productos, ya que son nombres químicos que muchas personas desconocen. Esto se comprobó en el estudio, ya que a pesar de que existe el interés, los consumidores no tienen información cercana para poder entender correctamente los términos nutricionales presentados en los productos. 
Kantar World Panel (2017) realizó un estudio en donde descubrió que cuatro de cada cinco peruanos no leen nunca las etiquetas o lo hace rara vez o de manera ocasional, porque simplemente no las entiende. En el presente estudio se observó que más del 40\% de los encuestados, lo primero que observan en sus productos es el etiquetado nutricional, sin embargo, son muchos los que no entienden a la perfección los términos nutricionales.

Siguiendo el modelo económico racional (Ariely, 2013), las personas cuentan con una memoria de capacidad limitada por lo que tienen muy poca información acerca de lo que se va a decidir y cierta o escasa incertidumbre de las consecuencias de sus actos. Es por ello que es necesario impactar en los usuarios para que en sus mentes se cree una motivación intrínseca por querer alimentarse saludablemente y conocer acerca de los elementos nutricionales. Esto se da, ya que los seres humanos solo conservan en su cabeza la información primordial; debido a esto se necesita que se haga mayor publicidad de concientización respecto a la nutrición en la población con el fin de generar cambios permanentes.

Naranjo (2016) señala que aspectos como el color del empaque, las bondades atribuidas por el boca a boca y la publicidad, ayudan a tomar una decisión de compra en los consumidores. Esto es cierto, ya que muchos encuestados se dejan guiar por heurísticos, los cuales son atajos mentales, haciendo que se decidan por los productos conocidos o alguno del que anteriormente se les haya hablado. Esto en sí no es beneficioso si es que la publicidad, el boca a boca y el empaque no están direccionados a guiar al consumidor en una alimentación saludable, pero si es que se logra concientizar a las personas e instaurar una cultura de alimentación saludable, estos heurísticos ayudarían a reducir la mala alimentación en la población.

Acorde con lo anterior, se necesita que las personas tomen conciencia respecto a estos temas para que puedan guiarse por la ruta central y no por la ruta periférica, ya que cuando se logre crear una cultura de alimentación saludable, los usuarios analizarán profundamente sus decisiones de compra y los productos que se llevarán a casa para su consumo. 


\section{Limitaciones del estudio}

La muestra del estudio fue de 120 personas, y no fue una muestra representativa frente a la población peruana que ronda los 31 millones 237 mil 385 habitantes (INEI, 2018). Del mismo modo no fue aleatoria, ya que se seleccionaron a las personas por conveniencia para ser encuestadas, sectorizándolas por su distrito de procedencia. Por lo tanto, los hallazgos encontrados en esta tesis no se pueden generalizar a toda la población peruana.

\section{Perspectiva de investigación a futuro}

La presente investigación sirve para que nos demos cuenta que muchas personas sí están al tanto de los elementos nutricionales, mas no de las etiquetas nutricionales. Se propone repetir este estudio en un año, ya que el Gobierno Peruano ha instaurado los etiquetados octogonales a partir del 17 de junio del 2019, por lo que se espera que las personas estén más informadas respecto a los límites nutricionales y los etiquetados. Esto es porque los etiquetados nutricionales en el Perú aún son novedosos y muchos todavía no están enterados sobre estas etiquetas nutricionales.

\section{Implicancias prácticas}

El 17 de junio del 2019 será obligatorio para todos los productos tener los etiquetados octogonales, y para la fecha muchos productos que se ofertan en tiendas y supermercados ya cuentan con el etiquetado octogonal como parte de la implementación de la Ley de Alimentación Saludable.

Sin embargo, muchas personas que viven en el Perú aún no están al tanto de la instauración del etiquetado octogonal, ya que cuando se realizó la encuesta, se les comentó a los encuestados que los etiquetados propuestos tenían la misma función que el etiquetado que se va a instaurar en nuestro territorio. Sin embargo, muchos de los encuestados preguntaron y comentaron que no sabían de qué etiquetado se estaba hablando. 
Lo anterior es preocupante, ya que el objetivo de los octógonos es hacer que las personas mejoren su alimentación y generen cambios permanentes en sus rutinas de compras, pero esto no podrá ser así, si es que no se promueve mayor difusión de ello. En otros países tales como Australia y Canadá que son los países propietarios de las opciones de etiquetado presentadas, se hicieron campañas de publicidad e información masivas para que estas reformas sean comprendidas eficientemente por la población. Es por ello que Canadá, según la Organización Mundial de la Salud (2016), es uno de los países que más se preocupa por la salud de su población. Asimismo, hace algunos años, como se ha mencionado en el presente estudio, Australia era uno de los países con los mayores índices de obesidad en el mundo; es por ello que instauraron el etiquetado de estrellas, y para que éste funcione, el Gobierno se alió con la mayor cantidad de medios, para que estas medidas sean satisfactorias y generen cambios en los australianos.

En el Perú, el etiquetado octogonal está presente hasta en los afiches publicitarios de productos que exceden los límites máximos para la salud; sin embargo, como se ha mencionado anteriormente, esto no funcionará si no se realiza la correcta enseñanza a las personas sobre qué significan y por qué hace mal consumir estos productos. Asimismo, se debe educar a los individuos sobre qué productos son considerados sanos, ya que productos simples, tales como frutas y verduras, son accesibles a la mayoría de personas. Cuando a muchas personas se les pregunta sobre productos sanos, los atribuyen a comida costosa, tal como se ha demostrado en la investigación. 


\section{CONCLUSIÓN}

A modo de conclusión, se puede determinar que el etiquetado canadiense fue mejor comprendido y aceptado por la muestra, ya que fue al que se le encontró menos desventajas y el único con el que se guiaron para responder si el cereal Chocapic es un producto saludable. Sin embargo, no importa qué etiquetado finalmente se instaure, si es que las personas no conocen sobre él; nadie podrá tomarlo en serio y no logrará cumplir su objetivo. Durante bastante tiempo en el Perú se estuvo discutiendo qué etiquetado se instauraría, el octogonal o el semáforo, pero realmente no importa por cuál se opte si no se enseña qué significa y para qué sirve.

Asimismo, siguiendo una de las teorías citadas en la investigación - el modelo económico racional - las personas siempre se guiarán por su intuición, y para que el etiquetado que se les muestre les genere una reacción, éste debe ser grande, notorio y debe hacer creer que les está dando a las personas un valor agregado a su producto; de esa forma dejarán de comprar los alimentos dañinos para la salud.

Por último, se debe aprovechar el interés de las personas sobre los elementos nutricionales y crear campañas de información masivas, ya que la única barrera que realmente aleja a las personas interesadas en su salud es la desinformación. 


\section{REFERENCIAS}

Aina Centro Tecnológico (2016). Consumidor: Transparencia, Diferenciación y Personalización. Recuperado de: https://www.ainia.es/html/ebooks/ainia_2016_insights_abril.pdf

Alexandra López. (2018). Mercado Negro. Estudio sobre vida saludable. Recuperado de: https://www.mercadonegro.pe/datum-presenta-estudio-sobre-vida-saludable/

Álvarez Blanco, R. (2011). Neuromarketing. New York, Estados Unidos, PRENTICEHALL

Apeim. (2010). Niveles socioeconómicos en Lima Metropolitana y Callao. Miraflores, Perú. Recuperado de: http://www.apeim.com.pe/wpcontent/themes/apeim/docs/nse/APEIM-NSE-2009-2010-LIMA.pdf

Apeim (2016). Niveles socioeconómicos 2016. Recuperado de: http://www.apeim.com.pe/wp-content/themes/apeim/docs/nse/APEIM-NSE2016.pdf

Arellano Marketing. (2018) ¿Qué tipo de etiquetado prefieren los consumidores? 2018, de Come Bien. Recuperado de: http://comebien.pe/que-tipo-de-etiquetadoprefieren-los-consumidores/

Ares, G. (2016) Evidencia científica sobre la influencia del etiquetado en la percepción y elección de alimentos y bebidas, Núcleo Interdisciplinario "Alimentación y Bienestar" Universidad de la República, Uruguay, Recuperado de: http://www.paho.org/hq/index.php?option=com_docman\&task=doc view\&gid= $\underline{40927 \& \text { Itemid }=270 \& \text { lang }=\text { en }}$

Audije, P. (2016). Association between body mass index (bmi) and height from birth to 5 years in Chilean preschool children, Chile (2016). Revista Médica de Chile, 29(110), pp. 12-14.

Bille, W., Freire, L., Waters, F., Rivas-Mariño, G. (2017). Semáforo nutricional de alimentos procesados: estudio cualitativo sobre conocimientos, comprensión, actitudes y prácticas en el Ecuador. 2017, de Revista Peruana de Medicina Experimental. Recuperado de:

http://www.rpmesp.ins.gob.pe/index.php/rpmesp/article/view/2762/2696

Becerra M. (febrero 28, 2018). Perú: Congreso aprobó híbrido de etiquetados semáforo y advertencias. 28 Feb 2018, de Perú Retail Recuperado de:

http://www.america-retail.com/peru/peru-congreso-aprobo-hibrido-deetiquetados-semaforo-y-advertencias/

Beltrán Salmón, L. (2011). Comunicación para la Salud del Pueblo Recuperado de: http://www.culturascontemporaneas.com/contenidos/2\%20Ensayo $\% 20$ Beltran $\%$ 20pp\%2017-65.pdf 
Bollard (2016). International Journal of Behavioral Nutrition and Physical Activity. Recuperado en: https://ijbnpa.biomedcentral.com/track/pdf/10.1186/s12966$\underline{016-0421-7}$

Bollard, T., Ninya, M., Walker, N., Cliona, L., Ni Mhurchu, G. (2016). Effects of plain packaging, warning labels, and taxes on young people's predicted sugarsweetened beverage preferences: an experimental study. 2016, de Bollard et al. International Journal of Behavioral Nutrition and Physical Activity. Recuperado de: https://ijbnpa.biomedcentral.com/track/pdf/10.1186/s12966-016-0421-7

Boyce, J. \& Kuijer, R. (2014). "El enfoque en el cuerpo de los medios Imágenes ideales desencadena la ingesta de alimentos entre comedores restringidos: una prueba de la teoría de la restricción y el modelo de probabilidad de elaboración". Comportamientos alimentarios.

Bracamonte, J.I., Beteta, J. (2018) Luz verde semáforo nutricional. Recuperado de: https://gestion.pe/blog/el-vino-de-la-semana/2018/05/luz-verde-semaforonutricional.html

Carissa, F. \& Etienne. (2016). Indicadores básicos Situación de Salud en las Américas. 2016, de Organización Panamericana de la Salud. Recuperado de: http://iris.paho.org/xmlui/bitstream/handle/123456789/31288/\%20IndicadoresBa sicos2016-spa.pdf?sequence $=1 \&$ isAllowed $=y$

CBC News. (2018). Proposed new federal food packaging labels target salt, sugar and fat. 2018, de CBC News. Recuperado de: http://www.cbc.ca/news/politics/foodlabels-warnings-announcement-1.4527917

Chen, S. \& Lee, K. (2008). "El papel de los rasgos de personalidad y los valores percibidos en la persuasión: una perspectiva de modelo de probabilidad de elaboración en compras en línea". Comportamiento social y personalidad: una revista internacional. 30 (240), pp 63-66.

Cialdini, R. (2001). Influencia: ciencia y práctica (4 ed.). Boston, MA: Allyn y Bacon.

CienciAmerica, (2017) Semáforo nutricional una ventana hacia el cuidado de la salud en el Ecuador (CienciAmerica, 2017) Recuperado de: http://cienciamerica.us/openjournal/index.php/uti/article/view/125/116

Matilde, M. \& Sanborn, C. (2014). "Comida Chatarra Estado y Mercado”. Universidad del Pacífico. Recuperado de: http://repositorio.up.edu.pe/bitstream/handle/11354/1608/SchwalbMar\%C3\%A Da2014.pdf? sequence $=1 \&$ isAllowed $=y$

Compañía Peruana de Investigación de Mercados y Opinión Pública (CPI). (1 al 16 de Febrero del 2018). Encuesta Perú urbano etiquetado nutricional en alimentos y bebidas envasadas. Recuperado de: http://cpi.pe/images/upload/paginaweb/archivo/23/opnac_etiqueta_saludable_pe $\underline{\text { ru_201803.pdf }}$ 
Congreso de la República. (2016). Recuperado de: http://www.leyes.congreso.gob.pe/Documentos/2016_2021/Proyectos_de_Ley y_de_Resoluciones_Legislativas/PL0151920170612.pdf

Congreso de la República del Perú. (2018). Ley 30021. Ley de promoción de la alimentación saludable para niños, niñas y adolescentes. Recuperado de: http://www.puntofocal.gov.ar/notific_otros_miembros/per89_t.pdf

Consumers International (2015). Nutrition labelling: a review of research on consumer and industry response in the global South. Recuperado de: https://www.ncbi.nlm.nih.gov/pmc/articles/PMC4306755/

Cornejo Fontalba, C.J. (Santiago, Marzo 2017). Ley de etiquetado nutricional: ¿modifican la conducta del consumidor? Santiago, Marzo 2017, de Universidad de Chile Sitio web:

http://repositorio.uchile.cl/bitstream/handle/2250/145826/Cornejo\%20Fontalba $\%$ 20Carolina.pdf?sequence $=1 \&$ is Allowed $=y$

Datum International (2018). Los peruanos no cuentan con la información nutricional necesaria para seguir una dieta saludable. Recuperado de: http://www.datum.com.pe/new_web_files/files/pdf/HAS.pdf

David Frederick (2016). A los hombres les preocupa la apariencia como a las mujeres. Recuperado de: https://psicologia-1/a-los-hombres-les-preocupa-tanto-laapariencia-como-a-las-mujeres.

Demoscópica y Universidad de Chile. Informe de resultados: Descripción de las percepciones y actitudes de los/as consumidores respecto a las medidas estatales en el marco de la implementación del Decreto 13/15. 2017. Recuperado de: http://web.minsal.cl/wp-content/uploads/2017/01/Informe-Per- cepciónConsumidores-ICEI.pdf

El Peruano (2018) Normas ley de etiquetado nutricional. Recuperado de: https://elperuano.pe/NormasElperuano/2018/06/16/1660606-1/1660606-1.htm

Espinoza Huerta, A. (2017). Revisión de la aplicación del etiquetado frontal - Food Consulting. 2017, de Food Consulting. Recuperado de:

http://www.foodconsulting.es/wp-content/uploads/Revision-de-la-aplicacion-deletiquetado-frontal-.pdf

Espinoza Huerta, A. (2013). Aplicación del etiquetado frontal como medida de salud pública y fuente de información nutricional al consumidor: una revisión. 2016, de Revista nutrición comunitaria, 14. 01-02. Recuperado de: http://www.renc.es/actualidad $2 . \operatorname{asp} ? \operatorname{cod}=48 \& \mathrm{pag}=1 \& \operatorname{codR}=9 \& \mathrm{v}=\&$ buscar $=\&$ anno

Espinoza, A., Luna, J., Morán, F. (2016) Revisión de la aplicación del etiquetado frontal como medida de Salud Pública y fuente de información nutricional al 
consumidor, México. Recuperado de: http://www.foodconsulting.es/wpcontent/uploads/Revision-de-la-aplicacion-del-etiquetado-frontal-.pdf

Espinoza, A., Luna, J., Morán, F. (2016). Aplicación del etiquetado frontal como medida de salud pública y fuente de información nutricional al consumidor: una revisión. Revista Española de Nutrición Comunitaria, 1, p.02-15.

FAO (2016). Alimentos saludables para las personas. Recuperado de: http://www.fao.org/3/am401s/am401s02.pdf

Flynn, B.S., Worden, J.K., Bunn, J.Y., Connolly, S.W. Dorwaldt, A.L. (2011). "Evaluación de los mensajes de televisión de prevención de fumar basados en el modelo de probabilidad de elaboración". Recuperado de: http://www.journalofadvertisingresearch.com/content/47/3/326

FMCG \& Retail. (2016). el 49\% de los peruanos sigue dietas bajas en grasa, ubicándose en el segundo lugar de latinoamérica. Recuperado de: https://www.nielsen.com/pe/es/insights/news/2016/El-49-por-ciento-de-losperuanos-sigue-dietas-bajas-en-grasa.html

Frigerio (2016). Comportamiento del consumidor. Recuperado de: http://200.16.86.50/Digital/33/revistas/blse/blse-frigerio34-34.pdf

Food Standards Australia New Zeland. (2013). Government Documents. Recuperado de: https://www.foodstandards.gov.au/publications/Documents/FSANZ\%20Technic al\%20Evaluation\%20-\%20Recommendation\%2043\%20pdf.pdf

Fundación Romero. (2018). Estudio de Neuromarketing confirma mayor efectividad del semáforo en etiquetado de alimentos. F.R., párr. 08.

García, I. (2015). Estrategia educativa sobre etiquetado nutricional en niños de 10 años de tres centros educativos privados. Recuperado de: http://recursosbiblio.url.edu.gt/tesiseortiz/2015/09/15/Garcia-Iris.pdf

Garzón, V. (2017). Cinco tendencias en alimentos y bebidas para 2018. ¿Qué demandará el consumidor? 2017, de Aina Centro Tecnológico. Recuperado de: http://www.ainia.es/tecnoalimentalia/consumidor/tendencias-alimentos-bebidas$\underline{2018 /}$

George Institute (2016), Case study: Incorporating Health Star Rating into NSW nutrition standards https://www.georgeinstitute.org/our-impact/case-studyincorporating-health-star-rating-into-nsw-nutrition-standards

Gobierno de México. (2015). Revisión del etiquetado frontal: Análisis de las Guías Diarias de Alimentación y su comprensión por estudiantes de nutrición en México. Recuperado de: https://www.insp.mx/epppo/blog/3225-etiquetado$\underline{\text { alimentacion.html }}$

Gómez, A. (miércoles 28 de febrero, 2018). Semáforos de alimentación saludable fueron aprobados en primera votación. 2018, de Altavoz. Recuperado de: 
https://altavoz.pe/2018/02/28/97290/semaforos-de-alimentacion-saludablefueron-aprobados-en-primera-votacion/

Government of Canada. (2018). Canadian Food Labeling Requirements. January, de Canadian Food Inspection Agency. Recuperado de: http://healthunit.org/wpcontent/uploads/CFIA_ACIA-Labelling-Presentation-for-Industry.pdf

Government of Canada (2018). Regulations Amending Certain Regulations Made Under the Food and Drugs Act (Nutrition Symbols, Other Labelling Provisions, Partially Hydrogenated Oils and Vitamin D). Recuperado de: http://gazette.gc.ca/rp-pr/p1/2018/2018-02-10/html/reg2-eng.html

Government of Canada (2018). Food Front-of-Package Nutrition Symbol Consumer Consultation. Recuperado de: https://www.healthyeatingconsultations.ca/frontof-package

Government of United Kingdom. (2016). Food labelling and packaging. 2016, de UK. Recuperado de: https://www.gov.uk/food-labelling-and-packaging

Griffin, E. (2012) Una primera mirada a la teoría de la comunicación, $8^{a}$ ed. McGrawHill: Nueva York, 205-207.

Health Canada (2018). Towards Front of Package Nutritions Labels of Canada. Recuperado de: https://www.foodpolitics.com/wpcontent/uploads/FOP_Canada_17.pdf

Hernández, M. (2003) Racionalidad y conducta del consumidor: el impacto de la utilidad de transacción y el precio de referencia. Recuperado de: http://www.tesis.uchile.cl/tesis/uchile/2003/hernandez_m/sources/hernandez_m. pdf

Hernández Sampieri, R., Fernández Collado, C., y Baptista Lucio, P. (2010). Metodología de la Investigación.

INEI (2018b). Encuesta demográfica y de salud familiar. Recuperado de: https://proyectos.inei.gob.pe/endes/2018/ppr/Indicadores_de_Resultados_de_los _Programas_Presupuestales_ENDES_Primer_Semestre_2018.pdf

INEI (2018a). Población peruana 2018. Recuperado de: https://www.inei.gob.pe/prensa/noticias/poblacion-del-peru-totalizo-31millones-237-mil-385-personas-al-2017-10817/

Infoglitz. (16 de Mayo del 2018). Conveniencia del semáforo nutricional en el etiquetado de alimentos procesados. Recuperado de: https://infoglitz.com/peru/conveniencia-del-semaforo-nutricional-en-eletiquetado-de-alimentos-procesados/

Kain, J., Corvalán, C., Lera L., Galván M., Weisstaub G., Uauy, R. (2016). Association between body mass index (BMI) and height from birth to 5 years in Chilean preschool children. 
Kahneman, D. (2011). Pensar rápido, pensar despacio. Barcelona: Random House Mondadori.

Krugmann, R.A. (2013). Uso de la etiqueta de información nutricional en la decisión de compra de alimentos por parte de consumidores de la ciudad de Valdivia, Chile. 2013, de Universidad Austral de Chile. Recuperado de:

http://cybertesis.uach.cl/tesis/uach/2013/fak.95u/doc/fak.95u.pdf

Lawarence, M. (2017) What you need to know about the health star rating on foods https://www.abc.net.au/news/health/2017-10-12/what-you-need-to-know-aboutthe-health-star-rating-on-foods/9040200

Ley No 30021, El Peruano, Lima, Perú, 17 de mayo del 2013.

Lindahl, C. (October 8, 2014). EU Rejects UK's 'Traffic Light' Nutritional Labeling. Recuperado de: http://www.oliveoiltimes.com/olive-oil-health-news/eu-rejectsuk-traffic-light- nutritional-labeling/41567

Marketing Social (2004) Luis Alfonso Pérez Romero. Pearson. Recuperado de: http://www.academia.edu/16491091/Marketing_social_P\%C3\%A9rez_Romero

McNeill, R., Brian, W. (1989). Revista de psicología de asesoramiento. Recuperado de: "Reconceptualizar la influencia social en el asesoramiento: el modelo de probabilidad de elaboración".

MINSA. (15 de marzo del 2018). Expertos internacionales expresan su respaldo a posición del Minsa sobre el etiquetado octogonal. 2018, de MINSA. Recuperado de: http://www.minsa.gob.pe/?op=51 $\neg \mathrm{a}=27076$

Moens, H. (2018). EC report on front - of - pack nutrition labelling. Recuperado de: https://ec.europa.eu/health/sites/health/files/nutrition_physical_activity/docs/ev 20180531_co03_en.pdf

Molinero, R. (2018). Los supermercados ya no podrán camuflar productos llenos de azúcar entre la comida sana. 1, de Playground. Recuperado de: https://www.playgroundmag.net/food/canada-etiquetasobesidad_28609543.html

Nielsen Global Health (2014). Generaciones más jóvenes buscan alimentos más saludables. Recuperado de:https://www.nielsen.com/pe/es/insights/news/2016/Generaciones-masjovenes-buscan-los-alimentos-mas-saludables.html

Nutrition Bulletin (2012). Productos saludables. Recuperado de: http://www.nutritionbulletin.uk/web/es/alimentacion/aprender_a_comer_bien/20 15/09/23/222637.php 
Organisation panaméricaine de la Santé (2016). Résumé du pays: Canadá. Recuperado de: https://www.paho.org/salud-en-las-americas-

2017/?page t es=informes+de+pais $\% 2$ Fcanada\&lang $=\mathrm{fr}$

Organización de las Naciones Unidas para la Alimentación y la Agricultura y Organización Panamericana de la Salud (2017) Panorama de la Seguridad Alimentaria y Nutricional en América Latina y el Caribe. Recuperado de: http://www.fao.org/americas/recursos/panorama/es/

Organización Panamericana de la Salud (2016) La OMS insta a tomar acción a nivel mundial para reducir el consumo de las bebidas azucaradas y su impacto sobre la salud. Recuperado de:

https://www.paho.org/per/index.php?option=com_content\&view=article\&id=35 95:la-oms-insta-a-tomar-accion-a-nivel-mundial-para-reducir-el-consumo-delas-bebidas-azucaradas-y-su-impacto-sobre-la-salud\&Itemid=900

Organización Panamericana de la Salud, Bolivia (2016) Ecuador, Chile y Bolivia defienden en la OPS el etiquetado de alimentos procesados. Recuperado de: https://www.paho.org/bol/index.php?option=com_content\&view=article\&id=19 25:etiqalimentosoct $16 \&$ Itemid $=481$

Organización de las Naciones Unidas para la Alimentación y la Agricultura (2011). La importancia de la educación nutricional. Recuperado de: http://www.fao.org/ag/humannutrition/3177902a54ce633a9507824a8e1165d4ae1d92.pdf

Petty, R.E., Cacioppo, J.T., Schumann, D. (1983). "Rutas centrales y periféricas hacia la efectividad de la publicidad: el papel moderador de la participación". Revista de investigación del consumidor, 7 (3), 115 - 145.

Pérez, B. (2017). Tendencias en el desarrollo de productos de alimentación para 2017. 2017, de Aina Centro Tecnológico. Recuperado de: http://www.ainia.es/tecnoalimentalia/consumidor/tendencias-en-el-desarrollode-productos-de-alimentacion-para-2017/

Publimetro. (15 de mayo del 2018). Conveniencia del semáforo nutricional en etiquetado de alimentos procesados. Recuperado de: https://publimetro.pe/actualidad/noticia-conveniencia-semaforo-nutricionaletiquetado-alimentos-procesados-74138

Redacción EC. (03.04.2018). Alimentación saludable: Ejecutivo observó ley que establece etiquetado de semáforo. 03.04.2018, de Diario El Comercio. Recuperado de: https://elcomercio.pe/peru/alimentacion-saludable-ejecutivoobservo-ley-establece-etiquetado-semaforo-noticia-508968

RPP Noticias. (28 de agosto del 2017). Alimentación saludable: Manual de etiquetado no cumple con informar. Recuperado de: http://rpp.pe/economia/economia/alimentacion-saludable-manual-de-etiquetadono-cumple-con-informar-noticia-1073137 
RPP Noticias. (2018). Canadá busca combatir la obesidad con un sistema de etiquetado similar al de Chile. Recuperado de: http://vital.rpp.pe/comer-bien/canada-buscacombatir-la-obesidad-con-un-sistema-de-etiquetado-similar-al-de-chile-noticia1112921

RPP (2018), Gobierno publicó el manual de advertencias que deberán llevar las etiquetas de productos procesados. Recuperado de: https://rpp.pe/politica/gobierno/gobierno-publico-el-manual-de-advertenciasque-deberan-llevar-las-etiquetas-de-productos-procesados-noticia-1129727

Ruiz, F. (2013). Comida Chatarra. Pág. 110. Recuperado de: http://repositorio.up.edu.pe/bitstream/handle/11354/1608/SchwalbMar\%C3\%A $\underline{\text { Da2014.pdf? sequence }=1 \& \text { isAllowed }=y}$

Sher, P.J., Lee, S. (2009). "El escepticismo del consumidor y las revisiones en línea: una perspectiva de modelo de probabilidad de elaboración". Comportamiento social y personalidad: una revista internacional, 198(100), pp. 50-54.

Te'eni-Harari, T., Lampert, Shlomo I., Lehman-Wilzig, S. (2007-09). "Procesamiento de información de la publicidad entre los jóvenes: el modelo de probabilidad de elaboración aplicado a la juventud"

Recuperado de: http://www.journalofadvertisingresearch.com/content/47/3/326

Universidad de Chile (2018) Ley De Etiquetado: Cambios en composición de alimentos y de conductas tras su implementación. Recuperado de:

https://inta.cl/evaluacion-de-panel-de-expertos-nacional-e-internacional-revelacambios-en-composicion-de-alimentos-y-conductas-de-las-personas-trasimplementacion-de-la-ley-de-etiquetado/

Valdebenito Verdugo, M. (Demoscópica) Labrín Elgueta, JM (ICEI) León Porath, V. (ICEI) Fierro Kalbhenn, S. (ICEI). (2015). Informe de resultados: descripción de las percepciones y actitudes de los/as consumidores respecto a las medidas estatales en el marco de la implementación del Decreto 13/15. Chile: Universidad de Chile.

Vásquez, I. (15 de Mayo del 2018). Alistan octógonos para etiquetado nutricional, según César Villanueva, de Perú 21. Recuperado de:

https://peru21.pe/economia/cesar-villanueva-alistan-octogonos-etiquetadonutricional-407095

Burgue, N. (2014). Controversial Food Health Star Rating System Reinstated. 1, de Australian Institute of Food Safety. Recuperado de: https://www.foodsafety.com.au/news/controversial-food-health-star-ratingsystem-reinstated

Vida, N. (2018). Aina. Alimentación Saludable la gran tendencia. Recuperado de: https://www.ainia.es/tecnoalimentalia/consumidor/alimentacion-saludable-lagran-tendencia-de-consumo-actual-7-claves-orientativas/ 
Vital RPP, Qué dice el Reglamento de la Ley de Alimentación Saludable. (2018).

Reglamento de la ley de alimentación Saludable. Recuperado de: https://vital.rpp.pe/salud/que-dice-el-reglamento-de-la-ley-de-alimentacionsaludable-noticia-1058758 
ANEXOS 


\section{Anexo 1}

En esta sección sólo se muestra un extracto de la ley, donde se citan los artículos más relevantes para la presente investigación.

Ley 30021
LEY DE PROMOCIÓN DE LA ALIMENTACIÓN SALUDABLE PARA
NIÑOS, NIÑAS Y ADOLESCENTES
Artículo 1. Objeto de la Ley
La presente Ley tiene por objeto la promoción y protección efectiva del
derecho a la salud pública, al crecimiento y desarrollo adecuado de las personas, a través
de las acciones de educación, el fortalecimiento y fomento de la actividad física, la
implementación de kioscos y comedores saludables en las instituciones de educación
básica regular y la supervisión de la publicidad, la información y otras prácticas
relacionadas con los alimentos y bebidas no alcohólicas dirigidas a los niños, niñas y
adolescentes para reducir y eliminar las enfermedades vinculadas con el sobrepeso, la
obesidad y las enfermedades crónicas conocidas como no transmisibles.

Artículo 3. Glosario

Para la aplicación de la presente Ley, se entiende por:

Alimentación saludable. Es una alimentación variada, preferentemente en estado natural o con procesamiento mínimo, que aporta energía y todos los nutrientes esenciales que cada persona necesita para mantenerse sana, permitiéndole tener una mejor calidad de vida en todas las edades.

Bonificación, regalo o premio. Todo bien, producto, servicio o beneficio ofrecido de forma gratuita u onerosa por adquirir el alimento o la bebida no alcohólica.

Promoción de ventas. Toda aquella acción destinada a incentivar la transacción de bienes o servicios en condiciones de oferta excepcionales y temporales, que aparecen como más ventajosas respecto de las condiciones de la oferta ordinaria o estándar. Puede consistir en la reducción de precios, incremento de cantidad, concursos, sorteos, canjes u otros similares.

Publicidad. Toda forma de comunicación difundida a través de cualquier medio o soporte, y objetivamente apta o dirigida a promover, directa o indirectamente, la imagen, marcas, productos o servicios de una persona, empresa o entidad en el ejercicio de su actividad comercial, industrial o profesional, en el marco de una actividad de concurrencia, promoviendo la contratación o la realización de transacciones para satisfacer sus intereses empresariales.

Publicidad dirigida a niños, niñas y adolescentes. Es aquella que, por su contenido, argumentos, gráficos, música, personajes, símbolos y tipo de programa en el que se difunde, es atractiva y está dirigida preferentemente a menores de 16 años.

Anunciante. Persona, natural o jurídica, que desarrolla actos cuyo efecto o finalidad directa o indirecta sea concurrir en el mercado y que, por medio de la difusión de publicidad, se propone: i) ilustrar al público, entre otros, acerca de la naturaleza, las 
características, propiedades o los atributos de los bienes o servicios cuya producción, intermediación o prestación constituye el objeto de su actividad; o ii) motivar transacciones para satisfacer sus intereses empresariales.

Publicidad testimonial. Toda publicidad que puede ser percibida por el consumidor como una manifestación de las opiniones, las creencias, los descubrimientos o las experiencias de un testigo, a causa de que se identifique el nombre de la persona que realiza el testimonial o ésta sea identificable por su fama o notoriedad pública.

Publicidad en producto. Toda publicidad fijada en el empaque, en el envase o en el cuerpo del producto.

Artículo 5. Observatorio de Nutrición y de Estudio del Sobrepeso y de Obesidad

5.1 Declárase de interés la creación del Observatorio de Nutrición y de Estudio del Sobrepeso y Obesidad, a cargo del Ministerio de Salud, como herramienta de monitoreo que permita suministrar información y hacer el análisis periódico de la situación nutricional de la población infantil y de la evolución de la tasa de sobrepeso y obesidad en niños, niñas y adolescentes y cuantificar sus efectos.

52 El Observatorio de Nutrición y de Estudio del Sobrepeso y Obesidad, tiene las siguientes funciones:

a) Recaba información sobre el ambiente obeso génico, los hábitos alimentarios y la actividad física, considerando el género y los diversos grupos socioeconómicos a nivel nacional.

b) Suministra información a todas las entidades que lo soliciten de la incidencia y prevalencia del sobrepeso y obesidad y de sus factores determinantes.

c) Realiza el seguimiento y la evaluación de la efectividad e impacto en la salud pública de las medidas adoptadas e implementadas en las políticas públicas para mejorar los niveles de nutrición y promover la actividad física.

d) Elabora un informe anual sobre el seguimiento y la evaluación de las estrategias adoptadas como políticas públicas y lo remite, en el primer trimestre del año siguiente, a la Comisión de Salud y Población y a la Comisión de Defensa del Consumidor y Organismos Reguladores de los Servicios Públicos del Congreso de la República.

e) Difunde un resumen del informe anual a través de los medios de comunicación masiva a nivel nacional.

Artículo 8. Publicidad de alimentos y bebidas no alcohólicas

La publicidad que esté dirigida a niños, niñas y adolescentes menores de 16 años y que se difunda por cualquier soporte o medio de comunicación social debe estar acorde a las políticas de promoción de la salud, no debiendo:

a) Incentivar el consumo inmoderado de alimentos y bebidas no alcohólicas, con grasas trans, alto contenido de azúcar, sodio y grasas saturadas, conforme a lo establecido en la presente Ley. 
b) Mostrar porciones no apropiadas a la situación presentada ni a la edad del público al cual está dirigida.

c) Usar argumentos o técnicas que exploten la ingenuidad de los niños, niñas y adolescentes, de manera tal que puedan confundirlos o inducirlos a error respecto de los beneficios nutricionales del producto anunciado.

d) Generar expectativas referidas a que su ingesta proporcione sensación de superioridad o que su falta de ingesta se perciba como una situación de inferioridad.

e) Indicar como beneficios de su ingesta la obtención de fuerza, ganancia o pérdida de peso, adquisición de estatus o popularidad.

f) Representar estereotipos sociales o que originen prejuicios o cualquier tipo de discriminación, vinculados con su ingesta.

g) Crear una sensación de urgencia o dependencia por adquirir el alimento o la bebida no alcohólica, ni generar un sentimiento de inmediatez o exclusividad.

h) Sugerir que un padre o un adulto es más inteligente o más generoso por adquirir el alimento o bebida que el que no lo hace; tampoco hacer referencia a los sentimientos de afecto de los padres hacia sus hijos por la adquisición o no del producto.

i) Promover la entrega de regalo, premio o cualquier otro beneficio destinado a fomentar la adquisición o el consumo de alimentos o bebidas no alcohólicas.

j) Utilizar testimonios de personajes reales o ficticios conocidos o admirados por los niños y adolescentes para inducir a su consumo.

k) Establecer sugerencias referidas a que se puede sustituir el régimen de alimentación o nutrición diaria de comidas principales, como el desayuno, el almuerzo o la cena. compulsiva.

1) Alentar ni justificar el comer o beber de forma inmoderada, excesiva o

m) Mostrar imágenes de productos naturales si estos no lo son.

Las afirmaciones y terminología referidas a la salud o a la nutrición deben estar sustentadas en evidencia científica y pueden ser requeridas en cualquier momento por la autoridad, de oficio o a pedido de cualquier ciudadano.

Fuente: Congreso de la República del Perú (2018) 


\section{ANEXO 2}

\section{Consentimiento Informado}

La presente investigación es conducida por PALOMA ANDREA ORTIZ MARTÍNEZ, para obtener la licenciatura en Comunicación de la UNIVERSIDAD DE LIMA, Perú. La meta de este estudio es determinar el impacto que tienen dos propuestas alternativas de etiquetado, canadiense y australiano, en los consumidores como modelo alterno al ya planteado por el Congreso de la República del Perú. Si usted accede a participar en este estudio, se le pedirá responder preguntas en una encuesta. Esto tomará aproximadamente 20 minutos de su tiempo. La participación en este estudio es estrictamente voluntaria. La información que se recoja será confidencial y con fines académicos; no se usará para ningún otro propósito fuera de los de esta investigación. Si tiene alguna duda sobre este proyecto, puede hacer preguntas en cualquier momento durante su participación en él. Igualmente, puede retirarse del proyecto en cualquier momento sin que eso lo perjudique en ninguna forma. Si alguna de las preguntas durante la encuesta le parece incómoda, tiene usted el derecho de hacérsela saber al investigador o de no responderla.

Desde ya le agradecemos su participación.

“Acepto participar voluntariamente en esta investigación. Me han indicado que tendré que responder preguntas en una encuesta, lo cual tomará aproximadamente 20 minutos. Reconozco que la información que yo provea en el curso de esta investigación es estrictamente confidencial y con fines académicos. Esta no será usada para ningún otro propósito fuera de los de este estudio sin mi consentimiento. He sido informado de que puedo hacer preguntas sobre el proyecto en cualquier momento y que puedo retirarme del mismo cuando así lo decida, sin que esto acarree perjuicio alguno para mi persona.” 


\begin{abstract}
ANEXO 3
"Encuestador": Realiza las 3 preguntas filtro para saber si es que el encuestado es candidato para responder la encuesta.
\end{abstract}

\title{
Encuesta:
}

Gracias por participar. Esta será una encuesta para el estudio que derivará en mi tesis de licenciatura de la Facultad de Comunicación de la Universidad de Lima. La información se recogerá anónimamente y el tratamiento de esta es confidencial y no hay respuesta buena o mala.

Complete la siguiente información:

¿Podría indicar su edad en años cumplidos?

¿Podría indicar su sexo? a) mujer b) hombre c) otro

¿Podría indicar su ocupación actual?

¿Podría indicar el número de sus hijos actuales?

¿Podría indicar el distrito en donde usted reside actualmente?

1. Qué tan de acuerdo o en desacuerdo está con el siguiente enunciado: "Entiendo los términos de la tabla nutricional como: sodio, azúcar, grasas, entre otras"

- Totalmente de acuerdo

- De acuerdo

- Ni de acuerdo ni en desacuerdo

- No estoy de acuerdo

- Totalmente en desacuerdo

2. ¿Conoce usted sobre los límites máximos para la salud acerca del sodio, azúcar, grasa en los productos?

- Sí

- No

3. Si respondió "sí" pase a la pregunta 4. Si respondió "no" a la pregunta anterior ¿cuál es la razón? (Marque solo una)

- Falta de interés

- Falta de información

- Otra razón (especifique) 
4. ¿Considera que es una persona que se preocupa por tener una alimentación saludable tanto para usted como para su familia?

- Sí

- No

5. Si respondió "no"pase a la pregunta 6. Si respondió "sí"a la pregunta anterior, responda lo siguiente: Cuando usted se dirige al supermercado a adquirir un producto saludable, ¿qué es lo primero que observa? (Marque solo uno)

- Producto reconocido en el mercado

- Etiquetado nutricional

- Tengan etiquetas que mencionen la palabra "light” o "bajo en calorías, azúcar"

- Empaque atractivo del producto

- Otro (especifique)

6. Cuando usted va al supermercado y tiene que elegir entre un producto u otro, ¿qué es lo que hace que finalmente escoja una opción? (Marque solo una opción)

- Marca

- Precio

- Información nutricional

- Otro: (especifique)

7. Para adquirir un producto en el supermercado ¿toma en cuenta las referencias que le han dado sus conocidos?

- Sí

- No

8. Cuando usted va al supermercado ¿tiene una lista de productos con las marcas específicas que desea comprar?

- Sí

- No

9. ¿Cómo son los hábitos de alimentación en su familia? (Marque solo una opción)

- Comen de todo

- Cuidan su dieta y alimentación

- Se consume bastante comida rápida y grasosa

- Consumen la comida hecha en casa

- Otro (especifique) 
10. ¿Cuál es la probabilidad que usted elimine totalmente los productos procesados de su alimentación?

- Bastante probable

- Algo probable

- Poco probable

- Cero probable

11. ¿Usted compraría o no compraría un producto que indica que es dañino para la salud?

a) Lo compraría

b) No lo compraría

Explique por qué:

12. ¿Usted considera que los productos saludables tienen un mayor precio en comparación a los demás productos del mercado?

- Sí

- No

Si respondió "no", pase a la pregunta 13. Sí respondió sí, responda lo siguiente: ¿Por qué cree usted que sucede esto?

13. ¿Usted considera que el precio sería uno de los motivos por los que compraría o dejaría de comprar un producto marcado como saludable?

- Sí, sería uno de los motivos.

- No, no sería uno de los motivos.

¿Podría explicar su respuesta? 
14. ¿Considera usted que los productos saludables están o no están sobrevalorados?

- Sí están sobrevalorados

- No están sobrevalorados

15. ¿Qué tan de acuerdo o en desacuerdo está con el siguiente enunciado: "Siempre que tengo que adquirir un nuevo producto observo la información nutricional"?

- Totalmente de acuerdo

- De acuerdo

- Ni de acuerdo ni en desacuerdo

- No estoy de acuerdo

- Totalmente en desacuerdo

La siguiente pregunta está dirigida únicamente para el encuestador, en las encuestas de los participantes no aparecerá esto.

Se procede a aleatorizar con la página web https://www.randomizer.org/para así lograr saber qué alternativa de etiquetado le tocara al participante.

Se procederá a mostrar la caja de Chocapic y continuar con las preguntas

Observar detalladamente si es que el encuestado fija su mirada en el etiquetado.

a) Sí fija su mirada

b) No fija su mirada

16. ¿Considera que el producto mostrado es saludable o no saludable para la salud?

a) Sí es saludable

b) No es saludable

17. Para poder entender la pregunta anterior, ¿En qué aspecto de este producto fue el que se basó? (Marque solo una respuesta)
a) Color del producto
b) Imágenes en el empaque
c) Marca
d) Sabor
e) Precio del producto
f) Calidad del producto
g) Otro (especifique)

Observe el etiquetado nutricional posicionado en la parte derecha superior de la caja de Chocapic. 
18. ¿Qué tan de acuerdo o en desacuerdo está con el siguiente enunciado: "Si existiera este tipo etiquetado en todos los productos empezaría a tomar más atención a los ingredientes dañinos que podrían tener los alimentos"?

- Totalmente de acuerdo

- De acuerdo

- Ni de acuerdo ni en desacuerdo

- No estoy de acuerdo

- Totalmente en desacuerdo

19. ¿Qué tan de acuerdo o en desacuerdo está con el siguiente enunciado: "Si existiera este etiquetado, cambiaría los productos que usualmente compro por otros más saludables"?

- Totalmente de acuerdo

- De acuerdo

- Ni de acuerdo ni en desacuerdo

- No estoy de acuerdo

- Totalmente en desacuerdo

20. ¿Qué tan de acuerdo o en desacuerdo está con el siguiente enunciado: "Si es que observo que uno de mis productos favoritos tiene este tipo de etiquetado en donde se me indica que posee porcentajes altos de azúcar, sodio o grasa, dejaría de comprarlo"?

- Totalmente de acuerdo

- De acuerdo

- Ni de acuerdo ni en desacuerdo

- No estoy de acuerdo

- Totalmente en desacuerdo

21. ¿Qué tan de acuerdo o en desacuerdo está con el siguiente enunciado: “El etiquetado observado hace que comprender la tabla de información nutricional sea mucho más sencillo y rápido"?

- Totalmente de acuerdo

- De acuerdo

- Ni de acuerdo ni en desacuerdo

- No estoy de acuerdo

- Totalmente en desacuerdo

22. ¿Considera que el diseño del etiquetado nutricional mostrado es sencillo de entender?

- Sí

- No

¿Podría indicar la razón? 
23. Si respondió “sí", pase a la pregunta 24. Si respondió "no" a la pregunta anterior, responda ¿Qué cambios cree usted que favorecerían la lectura de este tipo de etiquetado nutricional? (Marque solo una opción)
a) Cambiar el tamaño del etiquetado
b) Cambiar el color del etiquetado
c) Cambiar la ubicación del etiquetado
d) Otro (especifique)

24. ¿Cuáles cree usted que son las ventajas de instaurar este tipo de etiquetado nutricional?

25. ¿Cuáles cree usted que son las desventajas de instaurar este tipo de etiquetado nutricional? 